\title{
1 Evolving Infection Paradox of SARS-CoV-2: Fitness Costs Virulence?
}

3 A. S. M. Rubayet Ul Alam ${ }^{1 \square}$, Ovinu Kibria Islam ${ }^{1 \square}$, Md. Shazid Hasan ${ }^{1}$, Hassan M.

$4 \quad \mathrm{Al} \square$ Emran*, Md. Iqbal Kabir Jahid*, M. Anwar Hossain ${ }^{2,3 *}$

71 Department of Microbiology, Jashore University of Science and Technology, Jashore-7408,

8 Bangladesh

92 Jashore University of Science and Technology, Jashore-7408, Bangladesh

103 Department of Microbiology, University of Dhaka, Dhaka-1000, Bangladesh

\section{Correspondence}

14 M. Anwar Hossain, Jashore University of Science and Technology, Jashore-7408, 15 Bangladesh.

16 Email: hossaina@du.ac.bd, Contant: +8801708818101 


\section{ABSTRACT}

28 Severe Acute Respiratory Syndrome Coronavirus 2 (SARS-CoV-2) is continuously spreading

29 worldwide at an unprecedented scale in 2020. Within the first six months of the COVID-19

30 pandemic, it has evolved into six clades according to GISAID where three (G, GH, and GR)

31 are now globally prevalent $(>75 \%)$. Here we report the prevalence of these dominant clades,

32 both individually and in combination, with disease progression and death-case scenario that

33 leads to infer fitness of the SARS-CoV-2 by compromising its virulence. Unlike $\mathrm{G}$ or GH

34 clades, the GR clade strains represent a significant negative association with the death-case

35 ratio $(\mathrm{R}=-0.558, \mathrm{p}=0.019)$. Docking analysis revealed the molecular scenario behind more

36 infectiousness of S protein D614G mutation and reasoned more favorable binding of G614

37 with the elastase-2. Viral RNA-dependent-RNA-polymerase (RdRp) mutation p.P323L

38 facilitated significantly higher $(\mathrm{p}<0.0001)$ genome-wide mutations because more flexible

39 RdRp (mutant)-NSP8 interaction may accelerate replication. Superior RNA stability and

40 structural variation at NSP3:C241T might change the protein's conformation with a

41 speculated impact on 5'UTR, nucleocapsid, and replication complex interactions. Another

42 silent 5'UTR:C241T mutation might affect translational efficiency and viral packaging. These

43 G-featured coevolving mutations might together increase the viral load, quicker cell death,

44 and potentially a stronger immune response within the host, hence can modulate intra-host

45 genomic plasticity. In addition, viroporin ORF3a:p.Q57H mutation of GH-clade prevents ion

46 permeability by constricting the channel pore more tightly due to additional ionic interaction

47 with the cysteine $\left(\mathrm{C}^{81}\right)$ of transmembrane-domain-2, which possibly reduces viral release and

48 immune response. GR strains (four G clade mutations with N:p.RG203-204KR) would have

49 maintained more stability with stronger RNA interaction, a flexible linker region, and the

50 molecular effect of hypo-phosphorylation at SR-stretch. These empirical assumptions need

51 further retrospective and prospective studies to understand detailed molecular and

52 evolutionary events featuring the fitness and virulence of SARS-CoV-2.

\section{INTRODUCTION}

54 Severe acute respiratory syndrome coronavirus 2 (SARS-CoV-2) has caused the COVID-19 55 pandemic since the beginning of $2020^{1}$. This highly contagious virus spread in 213 countries 56 infecting over 11.3 million people including half a million deaths within the first six months $57 \mathrm{WHO}^{2}$. SARS-CoV-2 has possessed some extraordinary attributes that make it extremely 
infectious: high replication rate, large burst size, high stability in the environment, strong binding efficiency of S protein receptor-binding domain (RBD) with human angiotensinconverting enzyme 2 (ACE2) receptor, and additional furin cleavage site in S protein ${ }^{3-5}$. In addition to those, it has proofreading capability ensuring high-fidelity replication ${ }^{6}$. The virus contains four major structural proteins: spike glycoprotein $(\mathrm{S})$, envelope $(\mathrm{E})$, membrane $(\mathrm{M})$, and nucleocapsid $(\mathrm{N})$ proteins along with 16 nonstructural proteins (NSP1 to NSP16) and seven accessory proteins (ORF3a, ORF6, ORF7a, ORF7b, ORF8a, ORF8b, and ORF10) ${ }^{7,8}$.

65 Several researchers have demonstrated that mutations within those proteins may affect the 66 virulence of a strain $^{9-11}$. SARS-CoV-2 has been classified into six major clades, such as G, $67 \mathrm{GH}, \mathrm{GR}, \mathrm{S}, \mathrm{V}$, and L by GISAID based on the dominant mutations ${ }^{12}$. Yin ${ }^{13}$ reported the leader sequence mutation $241 \mathrm{C}>\mathrm{T}$ is coevolving with three other mutations, 3037C $>\mathrm{T}$ (NSP3: C318T), 14408C > T (RdRp: p.P323L), and 23403A > G (S: p.D614G). GISAID referred these coevolving mutation containing viruses as clade $\mathrm{G}$, a new viral strain over the wild-type ${ }^{11,14}$. This clade G viruses were dominant in Europe ${ }^{11}$ and the east coast of USA ${ }^{15}$ during the earlier stages of the pandemic that further spread in Southeast Asia ${ }^{16,17}$ and Oceania ${ }^{14}$. Remarkably, this mutation variant is reported to be more infective ${ }^{18}$ and observed to cause high mortality in USA ${ }^{19}$. The GR clade was classified with additional trinucleotide mutations at 28881-28883 (GGG>AAC) creating two consecutive amino acid changes, $\mathrm{R} 203 \mathrm{~K}$ and G204R, in N protein ${ }^{14}$. The GR strains are now the dominant type causing more than one-third of infection cases globally ${ }^{12}$. Another derivative of $G$ clade is GH, characterized by an additional ORF3a:p.Q57H mutation frequently found in the USA and 79 Europe ${ }^{20,21}$.

80 The most emphasized mutation is $\mathrm{D} 614 \mathrm{G}$ of $\mathrm{S}$ protein ${ }^{22}$ and the role of other dominant 81 mutations remains largely underestimated. However, the ORF3a:p.Q57H ${ }^{23}$ and 82 RdRp:p.P323L ${ }^{24}$ have recently been investigated while the effect of NSP3: C318T, 5'UTR: 83 C241T, and N:p.RG203-203KR is still being overlooked. Different mutations may work 84 independently or through synergistic interaction, thus it is difficult to spot exactly when a 85 single mutation or coevolving mutations become dominant in populations through 86 evolutionary fitness. Several coevolving mutations identified in SARS-CoV-2 may have 87 complementary roles in changing its virulence and the infection dynamics of COVID-19 88 pandemic. Thus, a lot of concerns remain unattended: since when the viruses possess a 89 'coevolving mutations'? Why a particular clades, GH and GR, are outcompeting their 90 speculative ancestor $\mathrm{G}$ clade? What are the impacts of these mutations on protein structures 
91 and their functional roles? Do these mutant proteins interact together? Is there any role of the 92 coevolved 'silent' mutations? Do these mutations have any impact on viral fitness and 93 virulence? We attempt to answer those sparkling questions by in silico molecular insights of

94 SARS-CoV-2 mutants and possible interactions of coevolved proteins.

95 This study aims to identify the prevalence of dominant coevolving mutations of $\mathrm{G}, \mathrm{GH}$, and 96 GR strains circulating in all over the world, individual and/or synergistic impact of those 97 mutants upon virulence in terms of viral entry and fusion, evasion of host cell lysis, 98 replication rate, ribonucleoprotein stability, protein-protein interactions, translational capacity and ultimately the combined effect on fitness and virulence.

\section{RESULTS AND DISCUSSION}

101 We represented the global scenario of the G, GH, and GR clades with both weekly and 102 monthly infection and death data. The correlation between the clade and death-case ratio has 103 been estimated and explained. Afterwards, the effects of each of the six mutations in S, 104 RdRp, ORF3a, N, 5'UTR and NSP3 were discussed with associated results. The overall 105 epistatic interactions of the mutant proteins and/or RNA was then depicted clearly (Figure 1) 106 with appropriate explanation. Finally, we endeavored to postulate using empirical 107 evolutionary theory how the virus is changing its virulence to impact the desired fitness.

\section{Global Emergence of a Dominant Coevolving Mutations}

109 Analysis of the SARS-CoV-2 genome sequences has revealed that 241C > T, 3037C > T,

$11014408 \mathrm{C}>\mathrm{T}$, and 23403A $>\mathrm{G}$ mutations were discretely identified among different viruses in

111 China on $24^{\text {th }}$ January of this year. These four mutations together in a single virus was first 112 detected in England on $3^{\text {rd }}$ February 2020 (Table 1). Since then, those mutations were found 113 to be coevolved altogether, formed clade $\mathrm{G}$, and has become the most dominant variant in 114 other regions of the world (Figure 2b), for example, escalating up to 85\% in May 2020 in 115 Southeast Asia ${ }^{16}$. The GR clade strain was the most predominant $(37 \%, n=7,756)$ in Europe, 116 whereas the GH clade has become more recognized in the Americas (North and South 117 America) by 59\% ( $\mathrm{n}=5,912)$ (Table 1$)$.

118 Our weekly based time-plot has depicted a gradual increase of G, GH, and GR viruses 119 altogether since the $10^{\text {th }}$ week (25 February - 3 March 2020) recording a sudden jump to $47 \%$ 120 in that week from a mere $10 \%$ of the previous week. The global COVID-19 cases 121 exponentially increased from the $10^{\text {th }}$ week with only 8,709 cases and infected almost 122500,000 people with ca. 40,000 deaths in just seven weeks while the G, GH, and GR strains 123 reached $80 \%$ (supplementary table S1). The death rate elevated at its peak (14\%) in early 
124 March (week 11) and gradually decreased to 4\% in mid-June (week 25). Correspondingly, 125 the number of GR strains is increasing from the $10^{\text {th }}$ week with a small fluctuation where the

$126 \mathrm{G}$ and $\mathrm{GH}$ strains each maintained a static ratio between $20-30 \%$ (Figure 2a).

127 The geographical distribution plot of the G, GH, and GR clades with infection and death128 cases delineates that the new infections began to rise exponentially with the increase of that 129 coevolved mutant variants in all regions except the West Pacific area (Figure 2b). West 130 Pacific region, which includes East Asian countries as well, identified a very low number of 131 infection cases and death per million (Figure 2b). Europe and America have a high rate of 132 infections as well as a high percentage of those variants. The reason may be a single 133 nucleotide deletion (delC) at a known variant site of transmembrane-protease-serine-2 134 (TMPRSS2), which is very rare in East Asia unlike Europe and North America ${ }^{25}$. The delC 135 allele facilitates entry of the $614 \mathrm{G}$ subtype (containing one of the coevolving mutations, $13623403 \mathrm{~A}>\mathrm{G}$ ) into the host cells and accelerates the spread of G, GH, and GR clades. Our 137 analysis has also found that the proportion of strains containing 23403A > G mutation was $13825 \%$ in East Asia and $>75 \%$ in Europe and America (data not shown).

139 The death-case ratio is decreasing globally while the GR mutants are increasing constantly 140 (Figure 2a). Our study found a significant negative association of GR clade mutants with the 141 death ratio as tested by the Pearson correlation coefficient $(\mathrm{R}=-0.558, \mathrm{p}=0.012)$. In contrast, 142 both $\mathrm{G}(\mathrm{R}=-0.166, \mathrm{p}=0.529)$ and $\mathrm{GH}(\mathrm{R}=-0.016, \mathrm{p}=0.951)$ clade mutants have no 143 significant association with death-case ratio. Regional data depicts a similar increase of GR 144 strains while the death ratio is decreasing, apart from in the Americas where we determined a 145 high abundance of GH clade strains (60.2\%). The increase of G strains and the death-case 146 ratio at the same time is observed in most regions except Eastern Mediterranean and 147 Southeast Asia, where a limited number of sequence data were produced. The change in GH 148 strains, however, does not show any impact on the death ratio (Figure 2b). Noteworthy, more 149 recent data have shown that $75 \%(4,323$ out of 5,873) of the sequenced strains in July 2020 150 resides in GR clade (data not shown).

\section{S Protein D614G Mutation Favors Elastase-2 Binding}

152 S: p.D614G mutation may facilitate the exposure of the cleavage domains of S1-S2 and S2' to 153 proteases, elastase-2, Furin, or TMPRSS2, as discussed by Eaaswarkhanth, et al. ${ }^{26}$. The 154 mutation possibly breaks hydrogen bonds and modulates the interactions between $\mathrm{S}$ protein 155 protomers ${ }^{22,27,28}$. Moreover, $\mathrm{G}^{614}$ mutation may increase $\mathrm{S}$ protein stability and participate in 156 N-linked glycosylation at N616 ${ }^{28}$. Several recent experiments have suggested that mutant 
$157\left(\mathrm{G}_{614}\right)$ protein contains a novel serine protease cleavage site at 615-616 that is cleaved by host 158 elastase-2, a potent neutrophil elastase playing important roles in inflammatory diseases of 159 human, more efficiently than wild protein, $\mathrm{D}_{614}{ }^{18,22,25,28}$.

160 This study has found interesting structural features of $\mathrm{S}$ protein while comparing and 161 superimposing the wild $\left(\mathrm{D}_{614}\right)$ over mutant $\left(\mathrm{G}_{614}\right)$. The secondary structure prediction and 162 surface accessibility analyses have shown that there is a slight mismatch at the S1-S2 junction $163\left({ }^{681}\right.$ PRRAR $\left.\downarrow S^{686}\right)$ where serine at $686\left(S^{686}\right)$ was found covered in $\mathrm{G}_{614}$ and exposed to the 164 surface in $\mathrm{D}_{614}$. However, $\mathrm{S}^{686}$ in both $\mathrm{G}_{614}$ and $\mathrm{D}_{614}$ are exposed to an open-loop region to 165 have possible contact with the proteases (supplementary Figure S1). Further investigation on 166 the aligned 3D structures showed no conformational change at the Furin or TMPRSS2 167 cleavage site (Figure 3c). We observed no structural variation in the surrounding residues of 168 the protease-targeting S1-S2 site (Figure 3c), which eliminates the assumption of Phan ${ }^{29}$.

169 The predictive 3D models and structural assessment of $\mathrm{D}_{614}$ and $\mathrm{G}_{614}$ variants also confirmed 170 that the cleavage site at $815-16$ of S2 subunit $\left({ }^{812} \mathrm{PSKR} \downarrow \mathrm{S}^{816}\right)$ or S2' 3,30 has no structural and 171 surface topological variation (Figure 3d-e). Rather, the superimposed 3D structures suggested 172 a conformational change in the immediate downstream region $\left({ }^{618}\right.$ TEVPVAIHADQLTPT $\left.{ }^{632}\right)$ 173 of $\mathrm{G}_{614}$ that was not observed in $\mathrm{D}_{614}$ variants (Figure 3a-b).

174 The elastase-2 restrictedly cut valine at 615 , due to its valine-dependent constriction of 175 catalytic groove ${ }^{31}$. The present sequence setting surrounding of $\mathrm{G}_{614}$ (P6$176{ }^{610}$ VLYQGV $\downarrow N C T E V{ }^{620}$-P'5) showed a higher enzymatic activity over the $\mathrm{D}_{614}$, which 177 cannot be completely aligned with previous works on the sequence-based substrate 178 specificity of elastase- ${ }^{32}$. However, the first misaligned residue of the $\mathrm{G}_{614}$, located at the $179 \mathrm{P}^{\prime} 4$ position $\left(\mathrm{T}^{618}\right)$, may also be important for binding with the elastase-2, and further down 180 the threonine $(\mathrm{T})$ at 618 , the residues may affect the bonding with the respective amino acids 181 of the protease. This changed conformation at the downstream binding site of $\mathrm{G}_{614}$ may help 182 to overcome unfavorable adjacent sequence motif in the mutant S protein as the elastase-2 183 substrate. Therefore, the simultaneous processing of the mutant $\mathrm{S}$ protein by 184 TMPRSS2/Furin/Cathepsin and elastase-2 facilitates a more efficient SARS-CoV-2 entry into 185 the host cells and cell-cell fusion ${ }^{18,25,28}$.

186 This study has further observed the possible association of S protein with elastase-2 and 187 found an increased binding affinity in the case of $\mathrm{G}_{614}$ (Table 2). Hence, the active sites of the 188 mutant protein interacted efficiently with more amino acids of elastase-2 (Table 3), possibly 
189 providing a better catalytic activity as shown by Hu, et al. ${ }^{28}$. The mutation may have changed 190 the structural configuration of the elastase-2 cleavage site in a way that the enzyme is facing 191 less challenge to get near to the cutting site of the altered protein (Figure 3a-b and 4). The 192 efficient cleaving of this enzyme, although located in an upstream position of S1-S2 junction, 193 may assist in releasing S1 from S2 and change the conformation in a way to get cleaved at 194 S2' site and help in the fusion process ${ }^{33,34}$.

195 Besides, this $\mathrm{G}^{614}$ amino acid mutation may have a destabilization effect on the overall 196 protein structure (Table 4 and Figure 3a-b), the deformed flexible region at or near $\mathrm{G}^{614}$ is the 197 proof of that destabilizing change (Figure 3f). Zhang, et al. ${ }^{35}$ explained less S1 shedding 198 through more stable hydrogen bonding between $\mathrm{Q}^{613}$ (glutamine) and $\mathrm{T}^{859}$ due to greater 199 backbone flexibility provided by glycine 614. Our analyses have provided the in silico proof 200 of this point by showing that the mutant protein was less stable than wild type protein by 201 missing a hydrophobic interaction with Phe592 (Figure 3g-h). Therefore, the overall 202 structural change may assist the mutant S protein by providing elastase-2 a better binding 203 space and attachment opportunity onto the cleavage site, thus providing a more stable 204 interaction with the S2 domain that increases the credibility of efficient infection.

205 Increased Flexibility of RdRp-NSP8 Complex: Compromise Proof-Reading Efficiency 206 with Replication Speed

207 The binding free energy $(\Delta \mathrm{G})$ of the RdRp-NSP8 complexes have been predicted as -10.6 and $208-10.5 \mathrm{Kcalmol}^{-1}$, respectively, in wild $\left(\mathrm{P}_{323}\right)$ and mutant $\left(\mathrm{L}_{323}\right)$ type that suggests more flexible 209 interaction for mutant protein (Table 4). The number of contacts made at the interface (IC) 210 per property and interacting amino acids increased between $\mathrm{L}_{323}$ and NSP8 (table 2 and 3).

211 Our analyses have identified that proline $\left(\mathrm{P}^{323}\right)$ or leucine $\left(\mathrm{L}^{323}\right)$ of $\mathrm{RdRp}$ can interact with the 212 aspartic acid $\left(\mathrm{D}^{112}\right)$, cysteine $\left(\mathrm{C}^{114}\right)$, valine $\left(\mathrm{V}^{115}\right)$, and proline $\left(\mathrm{P}^{116}\right)$ of NSP8 (Figure 5).

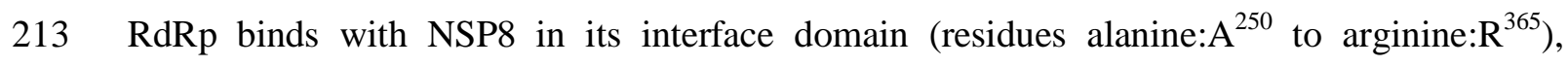
214 forming positively charged 'sliding poles' for RNA exit and enhance the replication speed 215 probably by extending the RNA-binding surface on NSP8 ${ }^{36,37}$. Another study reported that 216 the NSP8 binding sites on RdRp and the RNA exit tunnel were comparatively neutral and 217 conserved ${ }^{38}$. Besides, a zinc ion in the conserved metal-binding motif $\left(\mathrm{H}^{295}, \mathrm{C}^{301}, \mathrm{C}^{306}\right.$, and $218 \mathrm{C}^{310}$ ), close to the 323 residue, is responsible for maintaining the integrity of the $\mathrm{RdRp}$ 219 architecture ${ }^{38,39}$. We did not find any interaction of NSP8 with the zinc-binding residues of 220 RdRp proteins (Table 2 and Figure 5). Therefore, the P323L mutation within this conserved 
221 site of the RdRp interface domain may only affect the RdRp-NSP8 interaction without 222 changing metal binding affinity.

223 Recent reports on structural analyses revealed that the RdRp:p.P323L led to the stabilization

224 of the protein structure ${ }^{40,41}$. The results from the six state-of-the-art tools used in this study

225 have suggested that mutant $\left(\mathrm{L}_{323}\right)$ protein cannot be concluded as 'stable' from the ambiguous

$226 \Delta \Delta \mathrm{G}$ values (Table 4), rather the interaction with the adjacent amino acid ${ }^{40}$ mainly defined 227 the stability. Although the hydrophobic amino acid $\left(\mathrm{L}^{323}\right)$ embedded in the $\mathrm{L}_{323}$ protein, our 228 secondary structure analysis have indicated the presence of only loop structure in 323 229 position for both wild and mutant types (Figure S1). However, Chand et al. (2020) reported 230 the turn structures of 323 and 324 shifted into five sheets at positions 321, 322, 323, 324 and 231327 to bury leucine. The superimposed 3D structures solved this contradiction about 232 secondary structure by showing that there was no deviation in loop/turn structure of mutant 233 protein (supplementary Figure S3).

234 Overall, the mutation at 323 position, to some extent, stabilize the $\mathrm{L}_{323}$ structure, decrease the 235 exposed region, make the protein more rigid, and thus bind less strongly with the NSP8. 236 These variations may together increase the replication speed by exiting the processed RNA 237 genome from the RdRp groove structure more swiftly. The increasing replication speed might 238 be due to the perturbation of interaction between RdRp and NSP8 ${ }^{36,42}$, or the complex 239 tripartite interactions (RdRp, NSP8, and NSP14) responsible for the speculated decrease of 240 proof-reading efficiency ${ }^{6}$. Thus, RdRp mutants might increase the mutation rate by a trade241 off between high replication speed and low fidelity of the mutant polymerase ${ }^{43}$. Another 242 possibility might be the lower proof-reading efficiency of NSP14 that was not linked to the 243 replication speed ${ }^{6}$. Analysis of our study sequences have revealed that the frequency of 244 mutation (median=8) in $\mathrm{L}_{323}$ mutants $(\mathrm{n}=27,364)$ is significantly higher $(\mathrm{p}<0.0001)$ than the 245 frequency (median=6) of wild-type $\left(\mathrm{P}_{323}\right)$ strains $(\mathrm{n}=9,815)$. This increased mutation rate may 246 play a vital role in genetic drifts and provide next generations a better adaptation to adverse 247 environments.

\section{Q57H Substitution in ORF3a Viroporin: the Roles of Decreased Ion Permeability}

249 This study has found that the replacement of glutamine $\left(\mathrm{Q}^{57}\right)$ with positively charged 250 histidine $\left(\mathrm{H}^{57}\right)$ at 57 position of ORF3a transmembrane region 1 (TM1) does not change 251 secondary transmembrane helical configuration (supplementary Figure S1), and aligned 3D 252 structures have also shown no variation of TM1 in the monomeric state (Figure 6a). The 
253 mutant $\left(\mathrm{H}_{57}\right)$ protein has a non-significant increase in structural stabilization and a minimal 254 decrease in molecular flexibility (Table 4 and supplementary Figure S4). This is because of 255 the weak ionic interaction of $\mathrm{C}_{\alpha}$ with the sulfur atom of cysteine $\left(\mathrm{C}^{81}\right)$ in TM2 and hydrogen 256 bond of terminal $\mathrm{N}_{\zeta}$ of lysine $(61 \mathrm{~K})$ with one of the endocyclic nitrogens of $\mathrm{H}^{57}$ (Figure $6 \mathrm{~b}$ ).

257 Selection analysis predicted the accumulation of those mutations as a result of pervasive 258 positive selection with an increasing trend ${ }^{44}$. One possibility of this positive selection of 259 histidine over glutamine might be the role of $\mathrm{H}^{57}$ (TM1) in increasing constrictions wherein 260 the diagonal $\mathrm{C}^{81}$ (TM2) may assist through the ionic interaction (Figure 6b). Notably, the $\mathrm{Q}^{57}$ 261 in wild-type protein forms the major hydrophilic constriction within the ORF3a channel pore $262{ }^{45}$. Thus, further favorable increasing constrictions within the $\mathrm{H}_{57}$ protein channel pore and the 263 replacement of charge-neutral $\mathrm{Q}$ with a positive-charged $\mathrm{H}$ in the selectivity filter may reduce 264 the passing of positive ions such as $\mathrm{Ca}^{2+}, \mathrm{Na}^{+}$and $\mathrm{K}^{+}$by either electrostatic repulsion or 265 blocking ${ }^{46-49}$. This speculation for ORF3a mutant protein was supported by another study 266 that showed the reduction of ion permeability of $\mathrm{Na}^{2+}$ and $\mathrm{Ca}^{2+}$ through the $\mathrm{H}_{57}$, however, that 267 decrease was not found statistically significant $(\mathrm{p}>0.05){ }^{45}$.

268 The decrease intracellular concentration of cytoplasmic $\mathrm{Ca}^{2+}$ ions potentially reduces 269 caspase-dependent apoptosis of the host cell ${ }^{50}$, mainly supporting viral spread without 270 affecting replication ${ }^{23}$. Moreover, the ORF3a can drive necrotic cell death ${ }^{51}$ wherein the 271 permeated ions ${ }^{52}$ and the insertion of ORF3a viroporin into lysosome ${ }^{53}$ play vital roles. The $272 \mathrm{H}_{57}$ mutant may thus decrease pathogenicity and symptoms during the early stages of the 273 infection, i.e. reducing 'cytokine storm' in the host ${ }^{54}$. Besides, ORF3a was proved to affect 274 inflammasome activation, viral release, and cell death, as shown by Castaño-Rodriguez, et al.

27555 that the deletion of ORF3a reduced viral load and morbidity in animal models.

276 Even though similar proteins of ORF3a have been identified in sarbecovirus lineage infecting 277 bats, pangolins, and humans ${ }^{56}$, only one pangolin derived strains of 2017 in Guangxi, China 278 contains $\mathrm{H}^{57}$ residue as shown by our mutation analyses (supplementary Figure S5) and also 279 reported by Kern, et al. ${ }^{45}$. However, bat or civet did not contain this mutation in TM1 and the 280 flanking vicinity was not identical whereas the TM1 $\left({ }^{41}\right.$ LPFGWLIVGVALLAVFQSASKII $\left.{ }^{63}\right)$ 281 does not have amino acid substitutions for the strains of SARS-CoV-2 and pangolin282 coronaviruses (Figure S5a-b). The presence of this mutation in pangolin could be an 283 accidental case or might explain its impact on modulating host-specific immune response, 284 which needs functional experiment. A possible explanation behind that presence might be the 
more accustomed nature of the virus towards reverse transmission by being less virulent, i.e.

from human to other animals, as observed in recent reports ${ }^{57,58}$.

289 Our study has observed that the combined mutation (N: p.RG203-204KR) causes no conformational change in secondary and 3D structures (Figure S1 and Figure 7, respectively) of the conserved SR-rich region of the LKR (supplementary Figure S6), but there is a minor alteration in the degree of buried or exposed site (Figure 3). This result contradicted the prediction of ${ }^{59}$ about the change in the length and arrangements of the alpha-helix in the SRrich region. The superimposed 3D structures showed structural deviation, rather at ${ }^{231}{ }^{2 S K M S G K G Q Q Q Q G Q T V T ~}{ }^{247}$ of the LKR (Figure 9), corresponding to the high destabilization of the $\mathrm{KR}_{203-204}$ protein (Table 2).

Impedance to form particular SR-motif due to $\mathrm{RG} \rightarrow \mathrm{KR}$ mutation might disrupt the phosphorylation catalyzed by host glycogen synthase kinase-3 ${ }^{60}$. Similar hypophosphorylation events could arise due to the conversion of serine to nonpolar or neutral amino acids $\left(\mathrm{L}^{188 / 194 / 197}, \mathrm{I}^{193}\right.$, and $\mathrm{N}^{202}$ ) as represented in supplementary Table S2 and ${ }^{61}$. Consequently, the low phosphorylation level after entering into the cell should unwind the viral ribonucleoprotein (RNP) in a slower but more organized fashion that might have an impact upon translation and immune-modulation ${ }^{62-64}$. In $\mathrm{KR}_{203-204}$, replacement of a glycine with lysine that may increase the nucleocapsid ( $\mathrm{N}$ protein- RNA complex) stability by forming stronger electrostatic and ionic interactions due to increased positive charge ${ }^{65,66}$.

306 Besides, the more disordered orientation of the associated LKR ${ }^{62}$ and highly destabilizing 307 property of $\mathrm{KR}_{203-204}$ may assist in the packaging of a stable $\mathrm{RNP}^{67,68}$.

308 N protein also utilizes the dynamic nature of the intrinsically disordered linker region (LKR) 309 that controls its affinity towards M protein, self-monomer, 5'UTR, and cellular proteins ${ }^{69-71 .}$

310 The phosphorylation at the LKR site may play an essential role to regulate these interactions $311{ }^{65}$. It was speculated that $\mathrm{KR}^{203-204}$ attained more selective advantage ${ }^{44}$ over the other 312 mutations of $\mathrm{N}$ protein (Table S2), probably because of stronger RNA binding and 313 synchronized hypo-phosphorylation.

\section{Silent Mutations may not be Silent}

315 The C241T of 5'UTR (untranslated region), a single nucleotide change, or 'silent' mutation, 316 located at the UUCGU pentaloop part of the stem-loop region (SLR5B) has a potential role in 
317 viral packaging ${ }^{72}$. This pentaloop of 5'UTR remains unchanged and maintains a particular

318 structure ${ }^{72,73}$. The RNA secondary structural analysis in our study predicted that there is no

319 change in the 241T structure (supplementary Figure S7a). However, the silent mutation in the

320 loop region upstream to the ORF1a start codon (266-268 position) may involve in differential

321 RNA binding affinity to the ribosome and translational factors ${ }^{74}$.

322 In the case of multi-domain NSP3(papain-like protease), we have observed superior stability

323 of the RNA after gaining of the synonymous mutation 3037C $<\mathrm{T}$ (C318T) where wild and

324 mutant RNA structure has -151.63 and $-153.03 \mathrm{Kcal} / \mathrm{mol}$, respectively (Supplementary

325 Figure S7b-c). A more stable secondary structure of (+)ssRNA as observed in the mutant

326 NSP3 protein corresponds to the slower translational elongation. It contributes to a range of

327 abnormalities resulting in low translation efficiency, which affects posttranslational

328 modifications as a part of protein regulation ${ }^{75}$. Because silent mutations have an impact on

329 the ribosome occupancy time depending on the structural modification and mRNA stability

330 which guide co-translational folding kinetics of a protein ${ }^{75}$. This silent mutation is located

331 within the flexible loop of the NSP3 ubiquitin-like domain 1 (Ubl1). In SARS-CoV, Ubl1

332 was reported to bind with single-stranded RNA containing AUA patterns and interact with

333 the nucleocapsid (N) protein ${ }^{76,77}$. Besides, Ubl1 was likely to bind with several signature

334 repeats in $5^{\prime}$-UTR in SARS-CoV-2 genome ${ }^{78}$.

335 Synergistic Effects of Coevolving Mutations: Increasing Viral Fitness

336 The coevolving mutations have provided new insights into the dynamic epistatic network by 337 employing differential molecular interactions. The synergistic effects of the mutations were 338 reported to control viral fitness and virulence ${ }^{79-85}$. The viral fitness was determined by the 339 efficiency of viruses to spread throughout the population and infect more new victims ${ }^{86}$.

340 Evolution generally drives a pathogen to gain more fitness while reducing the virulence ${ }^{87}$ 341 during the natural course of mutations ${ }^{88}$.

342 Between two important G clade-featured coevolving mutations, the p:D614G of S protein and 343 p:P323L of RdRp, we observed no interlinked functional relationship. The former assists 344 mainly by more rapid entering into the host cells with an efficient elastase-2 activity and 345 higher aggressiveness of $\mathrm{G}_{614}$ mutant is related to elastase-2 or human neutrophil elastase 346 (hNE) concentration during inflammation ${ }^{89}$. The later one may boost up the replication by a 347 faster RNA processing (exiting) that can open up the avenue to generate strains with 348 significantly $(\mathrm{p}<0.0001)$ higher number of mutations. This increased mutation rate in $\mathrm{L}_{323}$ 
349 mutants can surpass the constant proof-reading fidelity ${ }^{90}$, with an average of $\sim 8$ (range $0-45$ )

350 mutations per strain $(n=37,179)$, and evolve a greater number of quasi-species.

351 The S protein and RdRp mutations, albeit seemingly unrelated, can cumulatively escalate the 352 infectiousness of the virus as a result of higher viral load and shorter burst time. This rapid 353 within-host replication might be directly correlated with the virulence, in turn, morbidity and 354 mortality rate ${ }^{91}$. This study also demonstrated that coevolving mutations, by acting together, 355 may benefit viral populations by incrementing the ability to produce a diverse quasi-species 356 that might be able to adapt in adverse climatic condition, evade the immune response, and 357 survive within different selective pressure ${ }^{92,93}$. The $\mathrm{S}$ protein mutation is related to human 358 allelic variation ${ }^{25}$, and may get an advantage in particular populations.

359 NSP3 is a scaffolding protein for the replication-transcription complex, and the possible 360 change in its structure may affect the overall dynamics of viral replication ${ }^{76,77}$. p.P323L 361 mutation of RdRp may change binding affinity to the Ub11 region of NSP3 ${ }^{94}$. The p.C241T 362 mutation, on its own, may affect the transcription and viral packaging, although we have not 363 found any possible association with the S, RdRp, and NSP3 mutant proteins.

364 The mutant $\mathrm{N}$ protein may have an impact on viral replication and transcription, like other 365 coronaviruses $^{71}$, through the binding with NSP3 protein that is linked to RdRp centered 366 replication complex. This $\mathrm{N}$ protein can affect the membrane stability by yet uncharacterized 367 interaction with the M protein, which should ultimately produce more stable virion particles $368{ }^{95-97}$. A stronger N protein-RNA complex provokes slower intracellular immune response ${ }^{63}$ 369 and can remain highly contagious and aggressive because of the concurrent presence of $\mathrm{G}$ 370 clade-featured S protein and RdRp mutations. In the case of mutant ORF3a protein, we have 371 not found any report that correlates with other coevolving mutations. $\mathrm{H}_{57}$ mutant, possibly 372 linked to the mild or asymptomatic cases, may allow the silent transmission and increase the 373 chance of viral spread by lowering the activation of inflammatory response, such as reduced 374 viral particle release and cytokine storm ${ }^{23,98,99}$.

375 The fittest viral strains will dominate in a population considering other selective parameters 376 associated with the virulence ${ }^{87,91}$. Public health interventions were able to create a selective 377 pressure to make a strain less virulent and highly competitive ${ }^{100}$, which might increase the 378 chance of viral transmission. The SARS-CoV-2 with multiple variants needs to be more 379 efficient to maintain the delicate evolutionary trade-off between fitness and virulence. A 380 recent publication on COVID-19 demonstrated a reduced viral load in the upper respiratory 
381 system for a particular genotype ${ }^{101}$ can impact the virulence, and may in turn influence viral

382 transmission and spread. In this study, we propose an empirical hypothesis (model) on SAR-

$383 \mathrm{CoV}-2$ that is how the fitness of the variants may cost virulence.

384 The presence of mostly G strains in the early pandemic period (starting weeks of March)

385 might be linked to a higher mortality rate (Figure 1). G strains were continuously present in

386 any region at a particular level ( 20\% among these clades) which could be the reason for

387 maintaining a high mortality rate. This stage of a pandemic might be linked to the initial lack

388 of awareness, hygienic practice, and social distancing that led to a large number of

389 transmissions. The high viral load and quick immune response will spread the $\mathrm{G}$ strains more

390 efficiently in a crowded area as shown in the case of Africa (Figure 1) where the lockdown

391 and other social interventions were not very strict ${ }^{102}$. The $G$ strains thus spread

392 unprecedentedly from Europe to the other part of the world.

393 The GH strains were mainly restricted to the USA and partly Eastern Mediterranean (Fig. 1) 394 and spread by cryptic ${ }^{103}$ and pre/a-symptomatic transmission ${ }^{104}$. These variants might trade-

395 off virulence by a slower release of virions, and in exchange, benefited from the induction of

396 low immune response in asymptomatic hosts. They were more fit at that time, in theory,

397 when the people are dealing with the pandemic in panic. The GH type was able to maximize

398 their transmission by residing within the host unknowingly and spread at ease.

399 The GR strains have increased in July 2020 with an average of $>80 \%$ submitted sequence in

400 GISAID (data not shown). This variant has possibly attained an advantage over G and GH

401 strains by a more orchestrated, delicately balanced synergistic effects. These epistatic effect

402 has increased the fitness by hiding the virus from immunity and increasing stability in the 403 environment, i.e. more transmissible through air and surface. The asymptomatic patient 404 infected with GR strains, similar to GH, would have a weaker immune response and shed the 405 virus for a longer period ${ }^{99}$.

406 The GH and GR strains have arisen during the initial phase of the pandemic with a limited 407 frequency and have not got the necessary fitness at that time. Both strains have evolved from 408 Europe and Australia like the laymen and spread quietly with the vigorous G strain. After the 409 public awareness and other social interventions, these variants, especially GR have availed 410 more fitness. Although $\mathrm{Hu}$ and Riley ${ }^{103}$ has recently reported a co-circulation of both $\mathrm{G}$ and 411 GH strains correlating the mortality in different states, how the association among multiple 412 clades would modulate the evolutionary dynamics is now a burning question. Our study 
413 analysis has considered the evolutionary trade-off between virulence and sustainable fitness

414 of these strains based on the global emergence of variants, their death-case ratio, structural

415 stability, and predicted molecular mechanisms. The relation of the host-pathogen

416 interactions, host allelic variations, and host immunity needs to correlate with virulence by in

417 vivo studies.

\section{CONCLUSION}

419 The frequency of new SARS-CoV-2 infections is increasing and the death rate is gradually 420 decreasing. Our study demonstrated that this paradoxical scenario is related to the effect of 421 the dominant coevolving mutations. The significant correlation of death-case ratio with GR 422 clade mutant could be linked with the signature mutation in nucleocapsid protein. GH clade 423 mutant may contribute to cryptic transmission by ORF3a-mediated low immune response in 424 asymptomatic hosts. $\mathrm{G}$ clade mutants, however, assist frequent transmission through severe 425 symptoms lead to the isolation of infected persons restricting further spreading. Therefore, 426 maintenance of the lock-down policy and social distancing to prevent viral transmission may 427 emerge less virulent strains and vice-versa, through host-pathogen genome plasticity.

\section{MATERIALS AND METHODS}

\section{Retrieval of Sequences and Mutation Analyses}

430 This study analyzed 37,275 high-coverage $(<1 \%$ Ns and $<0.05 \%$ unique amino acid 431 mutations) and complete (>29000 nucleotide) genome sequences with specified collection 432 date from a total of 37,953 sequences submitted to GISAID until July 6, 2020. The Wuhan433 Hu-1 (Accession ID- NC_045512.2) ${ }^{105}$ isolate was used as the reference genome. We 434 performed the alignment of genome sequences in MAFFT v7 ${ }^{106}$. A simple python script was 435 implemented to identify the number of sequences containing the targeted coevolving 436 mutations of the G, GH, and GR clades, and listed into a Microsoft Excel file.

437 Another python script partitioned the complete dataset into two subsets based on the RdRp: 438 C14408T mutation and estimated the genome-wide variations (single nucleotide changes) for 439 each strain. For this genome-wide mutation analysis, a total of 37,179 sequences (RdRp wild 440 type or 'C' variant: 9,815; and mutant or ' $\mathrm{T}$ ' variant: 27,364) were analyzed from our dataset. 441 The remaining 96 sequences containing the ambiguous bases (' $N$ ' or ' $\mathrm{Y}$ ') present in that 442 mutation site were excluded from the analysis. The frequency of mutations was tested for 443 significance with the Wilcoxon signed-rank test between RdRp 'C' variant and ' $T$ ' variant 
444 using IBM SPSS statistics 25. The Pearson correlation coefficient tests were performed to

445 observe the association of death-case ratio with $\mathrm{G}, \mathrm{GH}$, and GR clade mutants.

\section{Epidemiological Data Analysis and Time Plot Generation}

447 In this study, a weekly-based time plot of $\mathrm{G}, \mathrm{GH}$, and GR clade frequencies with infection 448 and death-cases was generated from 24 December 2019 until $6^{\text {th }}$ July 2020 that count a total 449 of 28 weeks (supplementary table S1). The total number of infections and deaths by weeks 450 were extracted from the WHO 2019-nCoV situation reports. The case-death ratio was 451 estimated by dividing the number of deaths of a particular week by the number of cases 452 identified in the earlier week based on the conservative assumption of a one-week interval 453 between diagnosis and death ${ }^{107}$. Regional time plots of those clades were also generated 454 monthly (from January to June) with frequencies of new infections, deaths, and death-case 455 ratio based on the available data on WHO situation reports ${ }^{108}$. The studied sequences were 456 divided into six regions; Europe $(n=21,168)$, Americas $(n=10,101)$, Eastern Mediterranean 457 ( $n=387)$, Southeast Asia $(n=1397)$, West Pacific $(n=3863)$, and Africa $(n=359)$.

458 Stability, Secondary and Three-Dimensional Structure Prediction Analyses of S, RdRp, 459 ORF3a and N Proteins

460 DynaMut ${ }^{109}$ and FoldX 5.0 ${ }^{110,111}$ were used to determine the stability of both wild and 461 mutant variants of N, RdRp, S, and ORF3a proteins. PredictProtein ${ }^{112}$ was utilized for 462 analyzing and predicting the possible secondary structure and solvent accessibility of both 463 wild and mutant variants of those proteins. The SWISS-MODEL homology modeling 464 webtool ${ }^{113}$ was utilized for generating the three-dimensional (3D) structures of the RdRp, S, 465 and ORF3a protein using 7c2k.1.A, 6xr8.1.A, and 6xdc.1.A PDB structure as the template, 466 respectively. I-TASSER ${ }^{114}$ with default protein modeling mode was employed to construct 467 the $\mathrm{N}$ protein 3D structure of wild and mutant type since there was no template structure 468 available for the protein. The built-in structural assessment tools (Ramachandran plot, 469 MolProbity, and Quality estimate) of SWISS-MODEL was used to check the quality of 470 generated structures.

\section{Molecular Docking of RdRp-NSP8 and S protein-Elastase2 Complex}

472 Determination of the active sites affected by binding is a pre-requisite for docking analysis. 473 We chose 323 along with the surrounding residues (315-324) of RdRp and the residues 110

474 to 122 of NSP8 monomer as the active sites based on the previously reported structure ${ }^{115}$. 
475 The passive residues were defined automatically where all surface residues were selected 476 within the $6.5^{\circ} \mathrm{A}$ radius around the active residues. The molecular docking of the wild and 477 predicted mutated RdRp with the NSP8 monomer from the PDB structure 7C2K was 478 performed using the HADDOCKv2.4 to evaluate the interaction ${ }^{116}$. The binding affinity of 479 the docked RdRp-NSP8 complex was predicted using the PRODIGY ${ }^{117}$. The number and 480 specific interfacial contacts (IC) for each of the complexes were identified.

481 The human neutrophil elastase (hNE) or elastase-2 (PDB id: 5A0C) was chosen for docking 482 of $\mathrm{S}$ protein, based on earlier reports ${ }^{28}$. Here we employed CPORT ${ }^{118}$ to find out the active 483 and passive protein-protein interface residues of hNE. The S protein active sites were chosen 484 based on the target region (594-638) interacting with the elastase-2. The passive residues of S 485 protein were defined automatically as mentioned for RdRp-NSP8 docking analysis. 486 Afterward, we individually docked wild (614D) and mutated (614G) S protein with the hNE 487 using HADDOCK 2.4. The binding affinity of the docked complexes, as well as, the number 488 and specific interfacial contacts (IC) were predicted as performed after RdRP-NS8 docking.

489 Mutational Analysis of Transmembrane Domain 1 of ORF3a and SR-domain of N 490 protein

491 The complete genome of 12 pangolins derived coronavirus strains, as well as 38 bat, civet 492 and human SARS-CoVs, were downloaded from GISAID and NCBI, respectively for the 493 mutational comparison between the SARS-CoV and SARS-CoV-2. We mainly targeted 494 transmembrane domain 1 (TM1), which covers 41 to 63 residues, of ORF3a to find the 495 identical mutation and scan overall variation in TM1. In the case of $\mathrm{N}$ protein, CoVsurver of 496 GISAID was used to study the frequent mutations other than our target ones (RG $\rightarrow$ KR: 203497 04) to bolster our speculation on the change and subsequent effects of those surrounding 498 variations on the functions of the protein. A generalized comparison between SARS-CoV and 499 SARS-CoV-2 reference sequences was performed to identify mutation in the SR-rich region 500 that will help to postulate on $\mathrm{N}$ protein functions of novel coronavirus based on previous 501 related research works on SARS-CoV.

\section{Analyzing RNA Folding prediction of 5'UTR and NSP3}

503 The Mfold web server ${ }^{119}$ was used with default parameters to check the folding pattern of 504 RNA secondary structure in the mutated 5'UTR and synonymous NSP3 regions. The 505 structure of complete mutant 5'UTR (variant 'T') was compared with the wild type (variant 506 ' $C$ ') secondary pattern as mentioned in the Huston, et al. ${ }^{73}$. Since the wild type (variant 'C' 
507 at $318^{\text {th }}$ nucleotide) RNA structure of the NSP3 was not available in the literature, we 508 generated the structure of mutant (variant ' $T$ ') to predict the RNA folding in the Mfold web 509 server. From the Mfold web server, we also estimated free energy change $(\Delta \mathrm{G})$ for wild and 510 mutant NSP3 RNA fold.

\section{REFERENCES}

5121 Lu, R. et al. Genomic characterisation and epidemiology of 2019 novel coronavirus: 513 implications for virus origins and receptor binding. The Lancet 395, 565-574 (2020).

5142 WHO. Coronavirus disease (COVID-19) Situation Report - 168 WHO situation 515 Reports (2020).

3 Hoffmann, M., Kleine-Weber, H. \& Pöhlmann, S. A multibasic cleavage site in the spike protein of SARS-CoV-2 is essential for infection of human lung cells. Molecular Cell (2020).

4 Hoque, M. N., Chaudhury, A., Akanda, M. A. M., Hossain, M. A. \& Islam, M. T. Genomic diversity and evolution, diagnosis, prevention, and therapeutics of the pandemic COVID-19 disease. PeerJ 8, e9689 (2020).

5 Petersen, E. et al. Comparing SARS-CoV-2 with SARS-CoV and influenza pandemics. The Lancet infectious diseases (2020).

6 Romano, M., Ruggiero, A., Squeglia, F., Maga, G. \& Berisio, R. A Structural View of SARS-CoV-2 RNA Replication Machinery: RNA Synthesis, Proofreading and Final Capping. Cells 9, 1267 (2020).

7 Rahman, M. S. et al. Epitope-based chimeric peptide vaccine design against S, M and E proteins of SARS-CoV-2 etiologic agent of global pandemic COVID-19: an in silico approach. PeerJ 8, e9572 (2020).

8 Yoshimoto, F. K. The Proteins of Severe Acute Respiratory Syndrome Coronavirus-2 (SARS CoV-2 or n-COV19), the Cause of COVID-19. The protein journal 39, 198216, doi:10.1007/s10930-020-09901-4 (2020).

9 Chen, J. Pathogenicity and transmissibility of 2019-nCoV-a quick overview and comparison with other emerging viruses. Microbes and infection (2020).

10 Islam, M. R. et al. Genome-wide analysis of SARS-CoV-2 virus strains circulating worldwide implicates heterogeneity. Scientific reports 10, 1-9 (2020).

11 Korber, B. et al. Tracking changes in SARS-CoV-2 Spike: evidence that D614G increases infectivity of the COVID-19 virus. Cell 182, 812-827. e819, doi:10.1016/j.cell.2020.06.043 (2020).

12 Shu, Y. \& McCauley, J. GISAID: Global initiative on sharing all influenza data-from vision to reality. Eurosurveillance 22, 30494 (2017).

13 Yin, C. Genotyping coronavirus SARS-CoV-2: methods and implications. Genomics 112, 3588-3596, doi:10.1016/j.ygeno.2020.04.016 (2020).

14 Mercatelli, D. \& Giorgi, F. M. Geographic and Genomic Distribution of SARS-CoV2 Mutations. Frontiers in Microbiology 11, doi:10.3389/fmicb.2020.01800 (2020).

15 Brufsky, A. Distinct Viral Clades of SARS $\square \mathrm{CoV} \square 2$ : Implications for Modeling of Viral Spread. Journal of medical virology (2020).

16 Islam, O. et al. Emergence of European and North American mutant variants of SARS-CoV-2 in Southeast Asia. (2020).

17 Ul Alam, A. R., Rafiul Islam, M., Shaminur Rahman, M., Islam, O. K. \& Anwar Hossain, M. Understanding the possible origin and genotyping of first Bangladeshi SARS $\square \mathrm{CoV} \square 2$ strain. Journal of Medical Virology (2020). 
55318 Korber, B. et al. Tracking changes in SARS-CoV-2 Spike: evidence that D614G increases infectivity of the COVID-19 virus. Cell (2020).

19 Becerra $\square$ Flores, M. \& Cardozo, T. SARS $\square$ CoV $\square 2$ viral spike G614 mutation exhibits higher case fatality rate. International Journal of Clinical Practice (2020).

20 Mercatelli, D. \& Giorgi, F. M. Geographic and Genomic Distribution of SARS-CoV2 Mutations. (2020).

21 Issa, E., Merhi, G., Panossian, B., Salloum, T. \& Tokajian, S. T. SARS-CoV-2 and ORF3a: Non-Synonymous Mutations and Polyproline Regions. BioRxiv (2020).

22 Grubaugh, N. D., Hanage, W. P. \& Rasmussen, A. L. Making sense of mutation: what D614G means for the COVID-19 pandemic remains unclear. Cell (2020).

23 Issa, E., Merhi, G., Panossian, B., Salloum, T. \& Tokajian, S. SARS-CoV-2 and ORF3a: Nonsynonymous Mutations, Functional Domains, and Viral Pathogenesis. Msystems 5 (2020).

24 Pachetti, M. et al. Emerging SARS-CoV-2 mutation hot spots include a novel RNAdependent-RNA polymerase variant. Journal of Translational Medicine 18, 1-9 (2020).

25 Bhattacharyya, C. et al. Global Spread of SARS-CoV-2 Subtype with Spike Protein Mutation D614G is Shaped by Human Genomic Variations that Regulate Expression of TMPRSS2 and MX1 Genes. bioRxiv (2020). in the SARS-CoV-2 spike (S) protein be associated with higher COVID-19 mortality? International Journal of Infectious Diseases (2020).

27 Korber, B. et al. Tracking changes in SARS-CoV-2 Spike: evidence that D614G increases infectivity of the COVID-19 virus. Cell (2020).

$28 \mathrm{Hu}$, J. et al. The D614G mutation of SARS-CoV-2 spike protein enhances viral infectivity. bioRxiv (2020).

29 Phan, T. Genetic diversity and evolution of SARS-CoV-2. Infection, genetics and evolution 81, 104260 (2020).

30 Belouzard, S., Chu, V. C. \& Whittaker, G. R. Activation of the SARS coronavirus spike protein via sequential proteolytic cleavage at two distinct sites. Proceedings of the National Academy of Sciences 106, 5871-5876 (2009).

31 Perona, J. J. \& Craik, C. S. Structural basis of substrate specificity in the serine proteases. Protein Science 4, 337-360 (1995).

32 Fu, Z., Thorpe, M., Akula, S., Chahal, G. \& Hellman, L. T. Extended cleavage specificity of human neutrophil elastase, human proteinase 3 , and their distant ortholog clawed frog PR3-three elastases with similar primary but different extended specificities and stability. Frontiers in Immunology 9, 2387 (2018).

$33 \mathrm{Li}, \mathrm{F}$. Structure, function, and evolution of coronavirus spike proteins. Annual review of virology 3, 237-261 (2016).

34 Walls, A. C. et al. Tectonic conformational changes of a coronavirus spike glycoprotein promote membrane fusion. Proceedings of the National Academy of Sciences 114, 11157-11162 (2017).

35 Zhang, L. et al. The D614G mutation in the SARS-CoV-2 spike protein reduces S1 shedding and increases infectivity. bioRxiv (2020).

36 Hillen, H. S. et al. Structure of replicating SARS-CoV-2 polymerase. bioRxiv (2020).

37 Yin, W. et al. Structural basis for inhibition of the RNA-dependent RNA polymerase from SARS-CoV-2 by remdesivir. Science (2020).

38 Kirchdoerfer, R. N. \& Ward, A. B. Structure of the SARS-CoV nsp12 polymerase bound to nsp7 and nsp8 co-factors. Nature communications 10, 1-9 (2019). 
60239 Gao, Y. et al. Structure of the RNA-dependent RNA polymerase from COVID-19

$603 \quad$ virus. Science 368, 779-782 (2020).

60440 Chand, G. B., Banerjee, A. \& Azad, G. K. Identification of novel mutations in RNAdependent RNA polymerases of SARS-CoV-2 and their implications on its protein structure. bioRxiv (2020).

41 Begum, F., Mukherjee, D., Das, S., Thagriki, D., Tripathi, P. P., Banerjee, A. K., \& Ray, U. Specific mutations in SARS-CoV2 RNA dependent RNA polymerase and helicase alter protein structure, dynamics and thus function: Effect on viral RNA replication. biorxiv.org (2020).

612

613

614

615

616

617

618

619 complex enzymes handling exceptional RNA genomes. Virus research 234, 58-73 (2017).

43 Eskier, D., Karakülah, G., Suner, A. \& Oktay, Y. RdRp mutations are associated with SARS-CoV-2 genome evolution. bioRxiv (2020).

44 Pond, S. Genomic diversity and divergence of SARS-CoV-2/COVID-19 from GISAID. (2020).

45 Kern, D. M. et al. Cryo-EM structure of the SARS-CoV-2 3a ion channel in lipid nanodiscs. BioRxiv (2020).

46 Malasics, A. et al. Protein structure and ionic selectivity in calcium channels: Selectivity filter size, not shape, matters. Biochimica et Biophysica Acta (BBA)Biomembranes 1788, 2471-2480 (2009).

47 Naranjo, D., Moldenhauer, H., Pincuntureo, M. \& Díaz-Franulic, I. Pore size matters for potassium channel conductance. Journal of General Physiology 148, 277-291 (2016).

48 Stephens, R. F., Guan, W., Zhorov, B. S. \& Spafford, J. D. Selectivity filters and cysteine-rich extracellular loops in voltage-gated sodium, calcium, and NALCN channels. Frontiers in Physiology 6, 153 (2015).

49 Suárez-Delgado, E. \& Islas, L. D. Ion Channels: A novel origin for calcium selectivity. Elife 9, e55216 (2020).

50 Kondratskyi, A., Kondratska, K., Skryma, R. \& Prevarskaya, N. Ion channels in the regulation of apoptosis. Biochimica et Biophysica Acta (BBA)-Biomembranes 1848, 2532-2546 (2015).

51 Yue, Y. et al. SARS-Coronavirus Open Reading Frame-3a drives multimodal necrotic cell death. Cell death \& disease 9, 1-15 (2018).

52 Pinton, P., Giorgi, C., Siviero, R. \& Zecchini, E. Rizzuto R. Bcl-2 and Ca 2, 14091418 (2006).

Nieva, J. L., Madan, V. \& Carrasco, L. Viroporins: structure and biological functions. Nature Reviews Microbiology 10, 563-574 (2012).

54 Ren, Y. et al. The ORF3a protein of SARS-CoV-2 induces apoptosis in cells. Cellular \& molecular immunology, 1-3 (2020).

55 Castaño-Rodriguez, C. et al. Role of severe acute respiratory syndrome coronavirus viroporins E, 3a, and 8a in replication and pathogenesis. MBio 9 (2018).

56 Boni, M. F. \& Lemey, P. Evolutionary origins of the SARS-CoV-2 sarbecovirus lineage responsible for the COVID-19 pandemic. Nature microbiology, doi:10.1038/s41564-020-0771-4 (2020).

57 Halfmann, P. J. et al. Transmission of SARS-CoV-2 in domestic cats. New England Journal of Medicine (2020).

58 Shi, J. et al. Susceptibility of ferrets, cats, dogs, and other domesticated animals to SARS-coronavirus 2. Science 368, 1016-1020 (2020). 
59 Ayub, M. I. Reporting Two SARS-CoV-2 Strains Based on A Unique TrinucleotideBloc Mutation and Their Potential Pathogenic Difference. Preprints doi:10.20944/preprints202004.0337.v1 (2020).

60 Tylor, S. et al. The SR-rich motif in SARS-CoV nucleocapsid protein is important for virus replication. Canadian journal of microbiology 55, 254-260 (2009).

61 Rahman, M. S. et al. Evolutionary dynamics of SARS-CoV-2 nucleocapsid protein (N protein) and its consequences. BioRxiv (2020).

62 Järvelin, A. I., Noerenberg, M., Davis, I. \& Castello, A. The new (dis) order in RNA regulation. Cell Communication and Signaling 14, 9 (2016).

63 Kikkert, M. Innate immune evasion by human respiratory RNA viruses. Journal of innate immunity 12, 4-20 (2020).

64 Kopecky-Bromberg, S. A., Martínez-Sobrido, L., Frieman, M., Baric, R. A. \& Palese, $\mathrm{P}$. Severe acute respiratory syndrome coronavirus open reading frame (ORF) 3b, ORF 6 , and nucleocapsid proteins function as interferon antagonists. Journal of virology 81, 548-557 (2007).

65 McBride, R., Van Zyl, M. \& Fielding, B. C. The coronavirus nucleocapsid is a multifunctional protein. Viruses 6, 2991-3018 (2014).

66 Sokalingam, S., Raghunathan, G., Soundrarajan, N. \& Lee, S.-G. A study on the effect of surface lysine to arginine mutagenesis on protein stability and structure using green fluorescent protein. PloS one 7, e40410 (2012).

67 Chang, C.-k., Hou, M.-H., Chang, C.-F., Hsiao, C.-D. \& Huang, T.-h. The SARS coronavirus nucleocapsid protein-forms and functions. Antiviral research 103, 39-50 (2014).

68 Haynes, C. \& Iakoucheva, L. M. Serine/arginine-rich splicing factors belong to a class of intrinsically disordered proteins. Nucleic acids research 34, 305-312 (2006).

69 Carlson, C. R. et al. Phosphorylation modulates liquid-liquid phase separation of the SARS-CoV-2 N protein. BioRxiv (2020).

70 Schuster, N. A. Using the nucleocapsid protein to investigate the relationship between SARS-CoV-2 and closely related bat and pangolin coronaviruses. BioRxiv (2020).

71 de Haan, C. A. \& Rottier, P. J. Molecular interactions in the assembly of coronaviruses. Advances in virus research 64, 165-230 (2005).

72 Rangan, R., Zheludev, I. N. \& Das, R. RNA genome conservation and secondary structure in SARS-CoV-2 and SARS-related viruses. BioRxiv (2020).

73 Huston, N. C., Wan, H., Tavares, R. d. C. A., Wilen, C. \& Pyle, A. M. Comprehensive in-vivo secondary structure of the SARS-CoV-2 genome reveals novel regulatory motifs and mechanisms. BioRxiv (2020).

74 Kristofich, J. et al. Synonymous mutations make dramatic contributions to fitness when growth is limited by a weak-link enzyme. PLoS genetics 14, e1007615 (2018).

75 Mitra, S., Ray, S. K. \& Banerjee, R. Synonymous codons influencing gene expression in organisms. Research and Reports in Biochemistry 6, 57 (2016).

76 Hurst, K. R., Ye, R., Goebel, S. J., Jayaraman, P. \& Masters, P. S. An interaction between the nucleocapsid protein and a component of the replicase-transcriptase complex is crucial for the infectivity of coronavirus genomic RNA. Journal of virology 84, 10276-10288 (2010).

77 Hurst, K. R., Koetzner, C. A. \& Masters, P. S. Characterization of a critical interaction between the coronavirus nucleocapsid protein and nonstructural protein 3 of the viral replicase-transcriptase complex. Journal of virology 87, 9159-9172 (2013). 
78 Serrano, P. et al. Nuclear magnetic resonance structure of the N-terminal domain of nonstructural protein 3 from the severe acute respiratory syndrome coronavirus. Journal of virology 81, 12049-12060 (2007).

79 Du, X. et al. Networks of genomic co-occurrence capture characteristics of human influenza A (H3N2) evolution. Genome research 18, 178-187 (2008). Rimmelzwaan, G. et al. Full restoration of viral fitness by multiple compensatory comutations in the nucleoprotein of influenza A virus cytotoxi
mutants. Journal of general virology 86, 1801-1805 (2005).

82 Chen, H., Zhou, X., Zheng, J. \& Kwoh, C.-K. Rules of co-occurring mutations Deng, L. et al. Network of co-mutations in Ebola virus genome predicts the disease lethality. Cell research 25, 753-756 (2015). characterize the antigenic evolution of human influenza $\mathrm{A} / \mathrm{H} 3 \mathrm{~N} 2, \mathrm{~A} / \mathrm{H} 1 \mathrm{~N} 1$ and $\mathrm{B}$ viruses. BMC medical genomics 9, 69 (2016).

83 Rimmelzwaan, G. F., Kreijtz, J. H., Bodewes, R., Fouchier, R. A. \& Osterhaus, A. D. Influenza virus CTL epitopes, remarkably conserved and remarkably variable. Vaccine 27, 6363-6365 (2009).

84 Lyons, D. M. \& Lauring, A. S. Mutation and epistasis in influenza virus evolution. Viruses 10, 407 (2018).

85 Nicoludis, J. M. \& Gaudet, R. Applications of sequence coevolution in membrane protein biochemistry. Biochimica et Biophysica Acta (BBA)-Biomembranes 1860, 895-908 (2018).

86 Di Giallonardo, F. \& Holmes, E. C. Viral biocontrol: grand experiments in disease emergence and evolution. Trends in microbiology 23, 83-90 (2015).

87 Geoghegan, J. L. \& Holmes, E. C. The phylogenomics of evolving virus virulence. Nature Reviews Genetics 19, 756-769 (2018).

88 Berngruber, T. W., Froissart, R., Choisy, M. \& Gandon, S. Evolution of virulence in emerging epidemics. PLoS Pathog 9, e1003209 (2013).

89 Mohamed, M. M., El-Shimy, I. A. \& Hadi, M. A. (BioMed Central, 2020).

90 Smith, E. C., Sexton, N. R. \& Denison, M. R. Thinking outside the triangle: replication fidelity of the largest RNA viruses. Annual Review of Virology 1, 111-132 (2014).

91 Skjesol, A. et al. IPNV with high and low virulence: host immune responses and viral mutations during infection. Virology journal 8, 1-14 (2011).

92 Pfeiffer, J. K. \& Kirkegaard, K. Increased fidelity reduces poliovirus fitness and virulence under selective pressure in mice. PLoS Pathog 1, e11 (2005).

93 Vignuzzi, M., Stone, J. K., Arnold, J. J., Cameron, C. E. \& Andino, R. Quasispecies diversity determines pathogenesis through cooperative interactions in a viral population. Nature 439, 344-348 (2006).

94 Lei, J., Kusov, Y. \& Hilgenfeld, R. Nsp3 of coronaviruses: Structures and functions of a large multi-domain protein. Antiviral research 149, 58-74 (2018).

95 Schoeman, D. \& Fielding, B. C. Coronavirus envelope protein: current knowledge. Virology journal 16, 1-22 (2019).

96 Escors, D., Ortego, J., Laude, H. \& Enjuanes, L. The membrane M protein carboxy terminus binds to transmissible gastroenteritis coronavirus core and contributes to core stability. Journal of virology 75, 1312-1324 (2001).

97 J Alsaadi, E. A. \& Jones, I. M. Membrane binding proteins of coronaviruses. Future Virology 14, 275-286 (2019).

98 Bai, Y. et al. Presumed asymptomatic carrier transmission of COVID-19. Jama 323, 1406-1407 (2020). 
99 Quan-Xin, L. et al. Clinical and immunological assessment of asymptomatic SARSCoV-2 infections. Nature medicine (2020).

100 Ebert, D. \& Bull, J. J. Challenging the trade-off model for the evolution of virulence: is virulence management feasible? Trends in microbiology 11, 15-20 (2003).

101 Lorenzo-Redondo, R. et al. A Unique Clade of SARS-CoV-2 Viruses is Associated with Lower Viral Loads in Patient Upper Airways. medRxiv (2020).

102 Abbas, K. et al. Routine childhood immunisation during the COVID-19 pandemic in Africa: a benefit-risk analysis of health benefits versus excess risk of SARS-CoV-2 infection. The Lancet Global Health (2020).

$103 \mathrm{Hu}$, Y. \& Riley, L. W. Dissemination and co-circulation of SARS-CoV2 subclades exhibiting enhanced transmission associated with increased mortality in Western Europe and the United States. medRxiv (2020).

104 He, X. et al. Temporal dynamics in viral shedding and transmissibility of COVID-19. Nature medicine 26, 672-675 (2020).

105 of the International, C. S. G. The species Severe acute respiratory syndrome-related coronavirus: classifying 2019-nCoV and naming it SARS-CoV-2. Nature microbiology 5, 536 (2020).

106 Rozewicki, J., Li, S., Amada, K. M., Standley, D. M. \& Katoh, K. MAFFT-DASH: integrated protein sequence and structural alignment. Nucleic acids research 47 , W5W10 (2019).

107 Wang, W., Tang, J. \& Wei, F. Updated understanding of the outbreak of 2019 novel coronavirus (2019 $\square \mathrm{nCoV}$ ) in Wuhan, China. Journal of medical virology 92, 441-447 (2020).

108 WHO. Coronavirus disease (COVID-19) Weekly Epidemiological Update and Weekly Operational Update. WHO situation Reports (2020).

109 Rodrigues, C. H., Pires, D. E. \& Ascher, D. B. DynaMut: predicting the impact of mutations on protein conformation, flexibility and stability. Nucleic acids research 46, W350-W355 (2018).

110 Schymkowitz, J. et al. The FoldX web server: an online force field. Nucleic acids research 33, W382-W388 (2005).

111 Delgado, J., Radusky, L. G., Cianferoni, D. \& Serrano, L. FoldX 5.0: working with RNA, small molecules and a new graphical interface. Bioinformatics 35, 4168-4169 (2019).

112 Rost, B., Yachdav, G. \& Liu, J. The predictprotein server. Nucleic acids research 32, W321-W326 (2004).

113 Waterhouse, A. et al. SWISS-MODEL: homology modelling of protein structures and complexes. Nucleic acids research 46, W296-W303 (2018).

114 Roy, A., Kucukural, A. \& Zhang, Y. I-TASSER: a unified platform for automated protein structure and function prediction. Nature protocols $\mathbf{5}, 725-738$ (2010).

115 Wang, Q. et al. Structural basis for RNA replication by the SARS-CoV-2 polymerase. Cell 182, 417-428. e413 (2020).

116 Van Zundert, G. et al. The HADDOCK2. 2 web server: user-friendly integrative modeling of biomolecular complexes. Journal of molecular biology 428, 720-725 (2016).

117 Xue, L. C., Rodrigues, J. P., Kastritis, P. L., Bonvin, A. M. \& Vangone, A. PRODIGY: a web server for predicting the binding affinity of protein-protein complexes. Bioinformatics 32, 3676-3678, doi:10.1093/bioinformatics/btw514 (2016). 
118 de Vries, S. J. \& Bonvin, A. M. CPORT: a consensus interface predictor and its performance in prediction-driven docking with HADDOCK. PloS one 6, e17695 (2011).

119 Zuker, M. Mfold web server for nucleic acid folding and hybridization prediction. Nucleic acids research 31, 3406-3415 (2003).

\section{Figure 1. Schematic diagram of SARS-CoV-2 replication in cell showcasing the related} to S, N, ORF3a, RdRp, NSP3 and 5'-UTR based epistatic interactions.

The replication cycle starts with the ACE2 receptor binding of the spike glycoprotein (S) as cornered at the top-left and finishes with the exocytosis at the top-right. The viruses which do not carry G-, GH- and/or GR-featured mutations in the S, N, ORF3a, RdRp, NSP3 and 5'UTR are denoted as the wild type where mutants contain those. Throughout the diagram, the red and green color icons such as proteins, genome, and virion represent the wild and mutant type, respectively. For a generalized virion, we used the blue color. Although this theme is not show the co-infection of both types, which might occur in rare occasions, we showed the comparative epistatic effects side-by-side fashion during the whole replication cycle that will make it easy to grasp. Related figure(s) for each protein are shown in the enclosed box. To mean the uncertainty or unknown effects of any mutant proteins/RNA structure, we used the 'question' mark in a pathway and on explanatory box. RdRp- RNA dependent RNA polymerase; NSP14- proof-reading enzyme of SARS-CoV-2; ER- endoplasmic reticulum; ERGIC- endoplasmic reticulum (ER) Golgi intermediate compartment.

\section{Figure 2. Global epidemiological scenario of G, GH and GR clades.}

(a) Weekly time-plot showing the percentage of G, GH and GR clade viruses with worldwide SARS-CoV-2 infections, death cases and death rates from 24 December, 2019 (collection date of first sequenced virus) to $15^{\text {th }}$ June 2020 where the weeks are shown in X axis. As low as 9 (for $2^{\text {nd }}$ week) to 5959 sequences (for $14^{\text {th }}$ Week) were analyzed to determine the ratio of $\mathrm{G}, \mathrm{GH}$ and GR clade (shown in right $\mathrm{Y}$ axis) in the sequenced viruses based on the availability of high coverage genomes submitted in GISAID until $6^{\text {th }}$ of July, 2020. For analyzing the death rate for each week, the number of detected infections and death cases (left Y axis) were collected from WHO situation reports. (b) Monthly region wise time-plot showing the percentage of G, GH and GR clades with infections, deaths and death rates from January to June of 2020 in 6 WHO regions. 21,168 sequences were analyzed for Europe, 10101 for Americas, 2863 for West Pacific, 1397 for Southeast Asia, 387 for Eastern Mediterranean and 359 for Africa. Infections and death cases were collected from WHO situation reports. The data labeling and values in the $\mathrm{X}$ and $\mathrm{Y}$ axis are same to figure $2 \mathrm{a}$. 
830 Figure 3. Different structural and stability comparison of wild and mutant spike

831 protein. Structural superposition of wild and mutant spike proteins (a-b); conformation in the

832 S1-S2 (c) and S2'sites (d-e); representation of vibrational entropy energy change on the

833 mutant type structure (f); and interatomic interaction prediction of both wild (g) and mutant

834 (h) types. For Figure a-e, the gray and yellow color represent the wild and mutant protein,

835 respectively. (a) The downstream (617-636) of D614G in wild (green) and mutant (red) $\mathrm{S}$

836 protein was focused. Overlapping of the wild $\left(\mathrm{D}_{614}\right)$ and mutant $\left(\mathrm{G}_{614}\right) \mathrm{S}$ protein showed

837 conformational change in the 3D structures. (b) However, the conformational change are in

838 the loop region (618-632) of the proteins thus may potentially play role in interacting with

839 other proteins or enzymes, such as elastase-2 as we focused in this work. (c) No change was

840 found in the S1-S2 cleavage site (685-686), depicted in blue color, of the wild and mutant

841 protein. (d) Surface and (e) cartoon $\left(2^{\circ}\right)$ structure of the superimposed wild and mutant

842 proteins where the S2' (pink) is situated in surface region and do not show any change in

843 accessibility in the residual loop region. (f) The mutant $\left(\mathrm{G}_{614}\right)$ protein showed higher

844 flexibility in the $\mathrm{G}^{614}$ (sticks) and its surroundings (red). The intra-molecular interaction

845 determined the overall stability of the (g) wild and (h) mutant structure where $\mathrm{C}_{\beta}$ of $\mathrm{D}^{614}$

846 (aspartic acid at 614; green stick modelled) had two hydrophobic interaction with the benzene

847 rings. This intramolecular contacts stabilize the $\mathrm{S}$ protein of wild type and missing of this

848 bond destabilize the mutant $\left(\mathrm{G}_{614}\right)$ protein. The mutant protein has glycine at 614 which has

849 less chance of interacting with other neighboring amino acids due to its shorter and nonpolar

850 R-group. The color code representing the bond type is presented in each $(\mathbf{g})$ and $(\mathbf{h})$.

851 Figure 4. The molecular docking of wild and mutant with elastase-2. Both the (upper

852 figure) wild $\left(\mathrm{D}_{614}\right)$ and (lower figure) mutant $\left(\mathrm{G}_{614}\right)$ version of $\mathrm{S}$ protein was shown in golden

853 color whereas the elastase-2 docked to $\mathrm{D}_{614}$ and $\mathrm{G}_{614}$ in blue and green color, respectively.

854 The enlarged views of the docked site were shown in separate boxes. (a) The possible docked

855 residues (stick model) on the wild S protein (warm pink) and elastase-2 (green) are 618(Thr)-

856 619(Glu)-620(Val) and 198(Cys)-199(Phe)-225:227 (Gly, Gly, Cys), respectively. The

857 aspartic acid at 614 is $17.3^{\circ} \mathrm{A}$ far away from the valine (101), apparently the nearest amino

858 acid of elastase-2 to the cleavage site (615-616). (b) The possible interacting residues (stick

859 model) on the mutant S protein (blue) and elastase-2 (warm pink) are 614(Gly)-618(Thr)-

860 619(Glu)-620(Val) and 101(Val)-103(Leu)-181(Arg)-222:227(Phe, Val, Arg, Gly, Gly, Cys),

861 and 236 (Ala) respectively. In this case, the glycine at 614 is only $5.4^{\circ} \mathrm{A}$ far away from the

862 valine (101), the nearest amino acid of elastase-2 to the cleavage site (615-616). 
863 Figure 5. The molecular interaction of mutant RdRp with NSP8. The mutant $\left(\mathrm{L}_{323}\right) \mathrm{RdRp}$

864 (pale green) and NSP8 (light blue) are interacting as shown in center of the lower figure and 865 an enlarged view of the docked site is presented above within a box. The leucine at 323 866 interacted with the Asp (112), Cys (114), Val (115), and Pro (116). The wild ( $\left.\mathrm{P}_{323}\right) \mathrm{RdRp}$ has 867 identical docking interactions with NSP8 (table 3), thus is not presented as separate figure 868 here.

869 Figure 6. The effect on transmembrane channel pore of ORF3a viroporin due to 870 p.Q57H mutation. (a) The wild $\left(\mathrm{Q}_{57}\right)$ and mutant $\left(\mathrm{H}_{57}\right)$ ORF3a protein are presented in light 871 gray and green color, respectively. The structural superposition displays no overall 872 conformation change, however the histidine at 57 position of mutant ORF3a (deep blue) has 873 slightly rotated from glutamine at same position of the wild protein (bright red). This change 874 in rotamer state at 57 residue may influence (b) the overall stability of $\mathrm{H}_{57}$ (upper part) over $875 \mathrm{Q}_{57}$ (lower part) because of ionic interaction of histidine (green; stick model) of 876 transmembrane domain 1 (TM1) with cysteine at 81 (yellow stick) of TM2. The color code 877 defined different bond types is shown in inlet.

878 Figure 7. Structural superposition of wild and mutant $\mathbf{N}$ protein. The light grey color 879 represents both wild $\left(\mathrm{RG}_{203-204}\right)$ and mutant $\left(\mathrm{KR}_{203-204}\right) \mathrm{N}$ protein. The linker region (LKR: 880 183-247 amino acids) of wild $\left(\mathrm{RG}_{203-204}\right)$ and mutant $\left(\mathrm{KR}_{203-204}\right)$ are in pale yellow and warm 881 pink color, respectively. (a) The aligned structures showed a highly destabilizing (table 2) 882 conformational change from 231 to 247 amino acids within LKR. Other regions of the N 883 protein, especially the SR-rich region (184-204 amino acids) where the mutations occur, do 884 not change. (b) A more emphasized look into the SR-rich and mutated sites (RG203-204KR) 885 of wild and mutant N protein represent slight deviation in the Ser (197) and Thr (198) while 886 only glycine (green) to arginine (blue) substitution at 204 position shows changing at rotamer 887 state. The enlarged view is shown in the bottom part.

888 Table 1. First occurrence, global frequencies and prevalent zones for each mutation and 889 coevolving mutation were shown.

\begin{tabular}{|c|c|c|c|}
\hline Mutation/Clade & $\begin{array}{c}\text { First occurrence } \\
\text { (date, country, } \\
\text { accession) }\end{array}$ & $\begin{array}{c}\text { Global Frequencies } \\
\text { (frequency, } \\
\text { percentage) }\end{array}$ & $\begin{array}{c}\text { Prevalent zone } \\
\text { (zone, frequency, } \\
\text { percentage) }\end{array}$ \\
\hline $\mathbf{2 4 1 C}>\mathbf{T}$ & $24-01-20$, China & $27,047(72.56 \%)$ & Europe $(16916,79.85 \%)$ \\
\hline
\end{tabular}




\begin{tabular}{|c|c|c|c|}
\hline $3037 \mathrm{C}>\mathrm{T}$ & $\begin{array}{l}\text { 24-01-20, China } \\
\text { EPI_ISL_451345 }\end{array}$ & $28,188(75.62 \%)$ & Europe $(17345,81.94 \%)$ \\
\hline $14408 C>T$ & $\begin{array}{l}\text { 24-01-20, China } \\
\text { EPI_ISL_422425 }\end{array}$ & $27,364(73.41 \%)$ & Europe $(16946,80.05 \%)$ \\
\hline $23403 A>G$ & $\begin{array}{l}\text { 24-01-20, China } \\
\text { EPI_ISL_451345 }\end{array}$ & $27,420(73.56 \%)$ & Europe $(16967,80.15 \%)$ \\
\hline $25563 G>T$ & $\begin{array}{l}\text { 05-02-20, Australia } \\
\text { EPI_ISL_480608 }\end{array}$ & $10,507(28.19 \%)$ & Americas $(6029,59.69 \%)$ \\
\hline 28881-3GGG >AAC & $\begin{array}{l}\text { 16-02-20, England } \\
\text { EPI_ISL_466615 }\end{array}$ & $9,595(25.74 \%)$ & Europe $(7794,36.82 \%)$ \\
\hline $\begin{array}{c}241 \mathrm{C}>\mathrm{T}, 3037 \mathrm{C}>\mathrm{T}, 14408 \mathrm{C}>\mathrm{T}, \\
23403 \mathrm{~A}>\mathrm{G}(\mathrm{G} \text { clade })\end{array}$ & $\begin{array}{l}\text { 03-02-20, England } \\
\text { EPI_ISL_464302 }\end{array}$ & $8,103(21.74 \%)$ & Europe $(6188,29.23 \%)$ \\
\hline $\begin{array}{c}241 \mathrm{C}>\mathrm{T}, 3037 \mathrm{C}>\mathrm{T}, 14408 \mathrm{C}>\mathrm{T}, \\
23403 \mathrm{~A}>\mathrm{G}, 25563 \mathrm{G}>\mathrm{T} \\
(\mathrm{GH} \text { clade })\end{array}$ & $\begin{array}{l}\text { 05-02-20, Australia } \\
\text { EPI_ISL_480608 }\end{array}$ & $9,421(25.27 \%)$ & Americas $(5912,58.53 \%)$ \\
\hline $\begin{array}{c}241 \mathrm{C}>\mathrm{T}, \text { 3037C }>\text { T, } 14408 \mathrm{C}>\mathrm{T}, \\
23403 \mathrm{~A}>\mathrm{G}, 28881- \\
\text { 3GGG }>\text { AAC } \\
\text { (GR Clade) }\end{array}$ & $\begin{array}{l}\text { 16-02-20, England } \\
\text { EPI_ISL_466615 }\end{array}$ & $9,467(25.39 \%)$ & Europe $(7756,36.64 \%)$ \\
\hline
\end{tabular}

890

891 Table 2. The scores of HADDOCK, PRODIGY ( $\Delta G$ and Kd (M) at 37.0 $\square$ ) for RdRp/NSP8 892 and Spike-Elastase docked complex.

\begin{tabular}{|c|c|c|c|}
\hline Variables & types & RdRp/NSP8 & Spike-Elastase \\
\hline \multirow{2}{*}{ HADDOCK score } & Wild & $-82.2+/-7.8$ & $-43.0+/-8.9$ \\
\hline & Mutant & $-118.3+/-2.5$ & $-61.9+/-4.5$ \\
\hline \multirow{2}{*}{$\Delta G\left(\right.$ kcal mol $\left.^{-1}\right)$} & Wild & -10.6 & -13.3 \\
\hline & Mutant & -10.5 & -13.7 \\
\hline \multirow{2}{*}{ Kd (M) at $37.0 \square$} & Wild & $3.5 \mathrm{E}^{-08}$ & $4.5 \mathrm{E}^{-10}$ \\
\hline & Mutant & $3.9 \mathrm{E}^{-08}$ & $2.3 \mathrm{E}^{-10}$ \\
\hline \multirow{2}{*}{$\begin{array}{c}\text { Number of } \\
\text { interfacial } \\
\text { contacts (ICs) per } \\
\text { property }\end{array}$} & Wild & $\begin{array}{c}\text { charged-charged (5); charged-polar } \\
\text { (9); charged-apolar (15); polar-polar } \\
\text { (2); polar-apolar (16); and apolar- } \\
\text { apolar (21) }\end{array}$ & $\begin{array}{l}\text { charged-charged (17); charged- } \\
\text { polar (22); charged-apolar } \\
\text { (32);polar-polar (5);polar-apolar } \\
\text { (31); and apolar-apolar (23) }\end{array}$ \\
\hline & Mutant & $\begin{array}{l}\text { charged-charged(5); charged-polar } \\
\text { (16);charged-apolar (19); polar-polar } \\
\text { (3);polar-apolar(15); apolar-apolar (23) }\end{array}$ & $\begin{array}{l}\text { charged-charged (13);charged- } \\
\text { polar (18); charged-apolar } \\
\text { (27);polar-polar (4); }\end{array}$ \\
\hline
\end{tabular}




\begin{tabular}{|c|c|c|c|}
\hline & & & $\begin{array}{c}\text { polar-apolar (28) and apolar-apolar } \\
(36)\end{array}$ \\
\hline $\begin{array}{l}\text { Associated amino } \\
\text { acids of Elastase-2 } \\
\text { with possible }\end{array}$ & Wild & $\begin{array}{l}\text { P323: Asp(112), Cys(114), Val(115) and } \\
\text { Pro (116) }\end{array}$ & $\begin{array}{l}605 \text { (Ser) and } 607 \text { (Gln): } 36 \text { (Arg); } \\
618 \text { (Thr): } 199 \text { (Phe); } 619 \text { (Glu): } \\
199 \text { (Phe), Cys (227); } 620 \text { (Val): } \\
198 \text { (Cys), 225:227(Gly, Gly, Cys) }\end{array}$ \\
\hline $\begin{array}{c}\text { docking } \\
\text { interactions (for } \\
\text { spike) or NSP8 } \\
\text { (for RdRp) }\end{array}$ & Mutant & $\begin{array}{l}\text { P323: Asp(112), Cys(114), Val(115) and } \\
\text { Pro (116) }\end{array}$ & $\begin{array}{c}614 \text { (Gly): } 101 \text { (Val); } 618 \text { (Thr): } 181 \\
\text { (Arg), 223-226(Val, Arg, Gly, Gly); } \\
619 \text { (Glu): } 103 \text { (Leu), 181(Arg), 222- } \\
225 \text { (Phe, Val, Arg, Gly), } 236 \text { (Ala); } \\
620 \text { (Val): } 223-227 \text { (Val, Arg, Gly, } \\
\text { Gly, Cys) }\end{array}$ \\
\hline
\end{tabular}

893 Table 3. Assess the effect of mutations on structural dynamics of NSP-12/ RDRP, Spike,

894 NS3 and N Protein of SARS CoV-2 using DynaMut. The value of $\Delta \Delta G<0$ indicates that

895 the mutation causes destabilisation and $\Delta \Delta \mathrm{G}>0$ represents protein stabilization. For

$896 \Delta \triangle$ SVibENCoM, positive and negative value denotes the increase and decrease of molecular

897 flexibility, respectively.

\begin{tabular}{|c|c|c|c|c|c|c|c|c|c|}
\hline $\begin{array}{c}\text { Protei } \\
\mathbf{n} \\
\text { Name }\end{array}$ & $\begin{array}{c}\text { Mutatio } \\
\text { n with } \\
\text { position }\end{array}$ & $\begin{array}{c}\Delta \Delta G \\
\text { DynaM } \\
\text { ut } \\
\text { kcal/mol }\end{array}$ & $\begin{array}{c}\Delta \Delta G \\
\text { ENCo } \\
\text { M } \\
\mathrm{kcal} / \mathrm{m} \\
\text { ol }\end{array}$ & $\begin{array}{c}\Delta \Delta G \\
\mathrm{mCSM} \\
\mathrm{kcal} / \mathrm{m} \\
\text { ol }\end{array}$ & $\begin{array}{c}\Delta \Delta G \\
\text { SDM } \\
\text { kcal/m } \\
\text { ol }\end{array}$ & $\begin{array}{c}\Delta \Delta G \\
\text { DUET } \\
\text { kcal/m } \\
\text { ol }\end{array}$ & $\begin{array}{c}\Delta \Delta G \\
\text { FoldX } \\
\text { (kcal/mo } \\
\text { l) }\end{array}$ & Results* & $\begin{array}{c}\Delta \Delta S_{V i b} \\
\text { ENCo } \\
M \\
\text { kcal.mo } \\
\mathbf{l}^{-1} \cdot \mathbf{K}^{-1}\end{array}$ \\
\hline $\mathrm{RdRp}$ & P323L & 1.054 & -0.441 & -0.264 & 0.700 & 0.118 & -0.733 & Stabilizing & -0.551 \\
\hline Spike & D614G & -0.769 & +0.408 & -0.492 & 2.530 & 0.195 & +0.289 & $\begin{array}{c}\text { Destabilizi } \\
n g\end{array}$ & 0.510 \\
\hline $\begin{array}{c}\text { ORF3 } \\
\text { a }\end{array}$ & Q57H & 0.275 & -0.128 & 0.788 & 0.520 & -0.464 & -1.438 & Stabilizing & -0.160 \\
\hline $\begin{array}{c}\mathrm{N} \\
\text { Protei } \\
\mathrm{n}\end{array}$ & $\begin{array}{c}\text { RG203- } \\
04 \mathrm{KR}\end{array}$ & - & - & - & - & - & -3.42262 & $\begin{array}{c}\text { Highly } \\
\text { Destabilizi } \\
\text { ng }\end{array}$ & - \\
\hline
\end{tabular}

898

$899 *$ The final result of the stability for each protein was determined based on the intra-molecular interactome

900 analysis. The difference in the free energy change in proteins are due to different calculative approaches of those

901 tools.

902 Supplementary Figure 1. Secondary structure prediction of (a) S protein, (b) ORF3a, (c)

903 N protein, and (d) RdRp. The wild and mutant type was presented for each protein. Here we

904 focused on the mutation position in the protein. The red and blue colors in the upper bar

905 means helix and strand structures where the blue and yellow colors represent exposed and

906 buried region, respectively. The blank space means loop and intermediate region. 
907 Supplementary Figure 2. Deformation and Fluctuations comparison between wild and

908 mutant $S$ proteins. (a) Ensemble normal mode analysis of wild $\left(\mathrm{D}_{614}\right)$ and mutant $\left(\mathrm{G}_{614}\right)$

909 types based on respective 3D structures and then aligned to compare the root-mean square

910 (RMS) fluctuations in angstrom $\left({ }^{\circ} \mathrm{A}\right)$. Helices and strands are shown in both top and bottom

911 of the images in gray and black colors, respectively. (b) Atomic fluctuation and (c)

912 deformation energy provide the amplitude of the absolute atomic motion and a measure for

913 the amount of local flexibility in the proteins where the magnitude is represented by thin to

914 thick tube colored blue (low), white (moderate) and red (high). We found no variation in the

915 fluctuation and deformation energy between the wild $\left(\mathrm{D}_{614}\right)$ and mutant $\left(\mathrm{G}_{614}\right)$ types.

916 Supplementary Figure 3. Superimposition of wild type $\left(\mathbf{P}_{\mathbf{3 2 3}}\right) \mathbf{R d R p}$ on mutant protein

917 ( $\left.\mathbf{L}_{\mathbf{3 2 3}}\right)$. The overlapping of wild on the mutant RdRp showed no structural deviation. The wild

918 and mutant RdRp were shown gray and pink colors where the specific region (310-340 amino

919 acids) of the $\mathrm{P}_{323}$ and $\mathrm{L}_{323}$ were colored in yellow and green, respectively.

920 Supplementary Figure 4. Deformation, Fluctuations, and Vibrational Entropy Energy

921 change between wild and mutant ORF3a proteins. (a) Ensemble normal mode analysis of

922 wild $\left(\mathrm{Q}_{57}\right)$ and mutant $\left(\mathrm{H}_{57}\right)$ types based on respective $3 \mathrm{D}$ structures and then aligned to

923 compare the root-mean square (RMS) fluctuations in angstrom $\left({ }^{\circ} \mathrm{A}\right)$. Helices and strands are

924 shown in both top and bottom of the images in gray and black colors, respectively. (b) The

925 vibrational entropy change upon mutation where blue color mutation site represents a

926 rigidification or stability of the ORF3a mutant protein structure. The amino acid $\mathrm{H}^{57}$ and its

927 surrounding region showed higher stability (less flexibility). (c) Atomic fluctuation and (d)

928 deformation energy provide the amplitude of the absolute atomic motion and a measure for

929 the amount of local flexibility in the proteins where the magnitude is represented by thin to

930 thick tube colored blue (low), white (moderate) and red (high). We found no variation in the

931 fluctuation and deformation energy between the wild $\left(\mathrm{Q}_{57}\right)$ and mutant $\left(\mathrm{H}_{57}\right)$.

932 Supplementary Figure 5. Mutation analysis showing the transmembrane region 1 (41933 LPFGWLIVGVALLAVFQSASKII-63 amino acids) of SARS-CoV-2 and other related

934 viruses of sarbecovirus lineages. (a) The pangolin coronavirus ORF3a protein alignment

935 with the SARS-CoV-2 showed that only P4L strain from Guangxi, China in 2017 has the $\mathrm{H}^{57}$

936 mutation. Other amino acids of TM1 are not changed for pangolin viruses. (b) Nine out of 23

937 amino acids of ORF3a are conserved for the sarbecovirus lineage. These are: F(43), W(45), 
$938 \mathrm{~L}(46), \mathrm{G}(49), \mathrm{V}(50), \mathrm{A}(51), \mathrm{V}(55), \mathrm{K}(61)$, and I(63). The black color line along the column

939 showed 57 position.

940 Supplementary Figure 6. Aligned SR-rich region of SARS-CoV and SARS-CoV-2

941 reference sequence. The region contained only two mutations that shows the relatedness of

942 this region and functional report of one can be deduced from another.

943 Supplementary Figure 7. RNA secondary structures of mutant 5'-UTR (241T) and

944 NSP3s. (a) RNA secondary structure of 5'-UTR (151-267 positions) was determined by the

945 Mfold web server. The changing position at 241 (91 in this image) showed ' $U$ ' instead of ' $C$ '

946 as found in wild-type. The change has no impact upon native secondary structure of stem-

947 loop region 5B (SLR5B). (b) RNA secondary structure of NSP3 (1-500 positions) was

948 presented in the figure. The mutated position is at 318, and there is a change from loop to

949 stem due to this mutation ( $\mathrm{C}>\mathrm{T}$ ) from wild type. From thermodynamic point of view, we

950 found that the wild and mutant RNA structure have -151.63 and $-153.03 \mathrm{Kcal} / \mathrm{Mol}$ stating the

951 superior stability of the mutated type.

952 Supplementary Table 1. Week-wise infection, death and death rate values associated

953 with three G, GH, and GR clades (groups).

\begin{tabular}{|c|c|c|c|c|c|c|c|}
\hline & Week & $\begin{array}{l}\text { No. of } \\
\text { Cases }\end{array}$ & $\begin{array}{l}\text { No. of } \\
\text { Deaths }\end{array}$ & $\begin{array}{c}\text { Death rate } \\
(\%)\end{array}$ & $\begin{array}{c}\text { G group } \\
(\%)\end{array}$ & $\begin{array}{c}\text { GH Group } \\
(\%)\end{array}$ & $\begin{array}{c}\text { GR Group } \\
(\%)\end{array}$ \\
\hline $\begin{array}{c}\text { Week } \\
1\end{array}$ & \multicolumn{2}{|c|}{ 24-30 Dec (w1) } & & & & & \\
\hline $\begin{array}{c}\text { Week } \\
2\end{array}$ & \multicolumn{2}{|c|}{31 Dec-6 Jan (w2) } & & & & & \\
\hline $\begin{array}{c}\text { Week } \\
3\end{array}$ & \multicolumn{2}{|c|}{ 7-13 Jan (w3) } & & & & & \\
\hline $\begin{array}{c}\text { Week } \\
4\end{array}$ & \multicolumn{2}{|c|}{ 14-20 Jan (w4) } & & & & & \\
\hline $\begin{array}{c}\text { Week } \\
5\end{array}$ & 21-27 Jan (w5) & 2516 & 80 & $10.2 \%$ & 0 & 0 & 0 \\
\hline $\begin{array}{l}\text { Week } \\
6\end{array}$ & $\begin{array}{l}28 \text { Jan-4 Feb } \\
\text { (w6) }\end{array}$ & 12798 & 256 & $3.8 \%$ & 0 & 0 & 0 \\
\hline $\begin{array}{l}\text { Week } \\
7\end{array}$ & 4-10 Feb (w7) & 19924 & 484 & $3.8 \%$ & $0.61 \%$ & $0.61 \%$ & 0 \\
\hline Week & 11-17 Feb (w8) & 28326 & 757 & $2.6 \%$ & $0.00 \%$ & $0.71 \%$ & $0.71 \%$ \\
\hline
\end{tabular}




\begin{tabular}{|c|c|c|c|c|c|c|c|}
\hline 8 & & & & & & & \\
\hline $\begin{array}{c}\text { Week } \\
9\end{array}$ & 18-24 Feb (w9) & 5999 & 745 & $5.7 \%$ & $7.24 \%$ & $1.45 \%$ & $1.45 \%$ \\
\hline $\begin{array}{c}\text { Week } \\
10\end{array}$ & $\begin{array}{l}25 \text { Feb-3 Mar } \\
\text { (w10) }\end{array}$ & 8709 & 343 & $8.0 \%$ & $24.01 \%$ & $11.48 \%$ & $11.89 \%$ \\
\hline $\begin{array}{c}\text { Week } \\
11\end{array}$ & 3-9 Mar (w11) & 18708 & 697 & $13.9 \%$ & $19.89 \%$ & $17.27 \%$ & $22.52 \%$ \\
\hline $\begin{array}{c}\text { Week } \\
12\end{array}$ & $\begin{array}{l}\text { 10-16 Mar } \\
\text { (w12) }\end{array}$ & 53813 & 2594 & $13.2 \%$ & $18.28 \%$ & $26.85 \%$ & $13.48 \%$ \\
\hline $\begin{array}{c}\text { Week } \\
13\end{array}$ & $\begin{array}{l}\text { 17-23 Mar } \\
\text { (w13) }\end{array}$ & 153819 & 7083 & $11.0 \%$ & $20.33 \%$ & $27.70 \%$ & $16.00 \%$ \\
\hline $\begin{array}{c}\text { Week } \\
14\end{array}$ & $\begin{array}{l}\text { 24-31 Mar } \\
\text { (w14) }\end{array}$ & 320527 & 16875 & $9.7 \%$ & $21.55 \%$ & $30.04 \%$ & $20.84 \%$ \\
\hline $\begin{array}{c}\text { Week } \\
15\end{array}$ & $\begin{array}{l}31 \text { Mar-6 Apr } \\
\text { (w15) }\end{array}$ & 460066 & 31189 & $8.5 \%$ & $22.03 \%$ & $31.20 \%$ & $25.24 \%$ \\
\hline $\begin{array}{c}\text { Week } \\
16\end{array}$ & 7-13 Apr (w16) & 493362 & 39038 & $8.3 \%$ & $22.76 \%$ & $21.69 \%$ & $35.38 \%$ \\
\hline $\begin{array}{c}\text { Week } \\
17\end{array}$ & $\begin{array}{l}\text { 14-20 Apr } \\
\text { (w17) }\end{array}$ & 469758 & 40826 & $7.6 \%$ & $23.39 \%$ & $21.99 \%$ & $38.75 \%$ \\
\hline $\begin{array}{c}\text { Week } \\
18\end{array}$ & $\begin{array}{l}\text { 21-28 Apr } \\
\text { (w18) }\end{array}$ & 480979 & 35712 & $7.7 \%$ & $26.90 \%$ & $23.17 \%$ & $34.87 \%$ \\
\hline $\begin{array}{c}\text { Week } \\
19\end{array}$ & $\begin{array}{l}28 \text { Apr-4 May } \\
\text { (w19) }\end{array}$ & 481672 & 37007 & $7.4 \%$ & $21.85 \%$ & $32.53 \%$ & $35.63 \%$ \\
\hline $\begin{array}{c}\text { Week } \\
20\end{array}$ & $\begin{array}{l}\text { 05-11 May } \\
\text { (w20) }\end{array}$ & 488912 & 35491 & $5.9 \%$ & $21.97 \%$ & $28.78 \%$ & $39.05 \%$ \\
\hline $\begin{array}{c}\text { Week } \\
21\end{array}$ & $\begin{array}{l}\text { 12-18 May } \\
\text { (w21) }\end{array}$ & 529973 & 28694 & $5.0 \%$ & $28.09 \%$ & $25.38 \%$ & $37.13 \%$ \\
\hline $\begin{array}{c}\text { Week } \\
22\end{array}$ & $\begin{array}{l}\text { 19-25 May (w } \\
\text { 22) }\end{array}$ & 592942 & 26558 & $4.7 \%$ & $23.88 \%$ & $34.29 \%$ & $33.96 \%$ \\
\hline $\begin{array}{c}\text { Week } \\
23\end{array}$ & $\begin{array}{l}26 \text { May- } 1 \text { Jun } \\
\text { (w23) }\end{array}$ & 653341 & 27652 & $3.8 \%$ & $21.63 \%$ & $19.71 \%$ & $47.60 \%$ \\
\hline $\begin{array}{c}\text { Week } \\
24\end{array}$ & 2-8 Jun (w24) & 736467 & 24537 & $3.7 \%$ & $22.28 \%$ & $29.87 \%$ & $36.46 \%$ \\
\hline $\begin{array}{c}\text { Week } \\
25\end{array}$ & 9-15 Jun (w25) & 783371 & 27145 & $4.4 \%$ & $23.16 \%$ & $23.16 \%$ & $48.59 \%$ \\
\hline
\end{tabular}


955 Supplementary Table S2: Amino acid change in $\mathbf{N}$ protein SR rich region where the 956 frequency is $>\mathbf{3 0 0}$.

\begin{tabular}{|c|c|c|c|}
\hline WildtypeAA & $\underline{\text { Position }} \uparrow$ & $\underline{\text { MutatedAA }}$ & Frequency \\
\hline S & 194 & L & 2589 \\
S & 197 & L & 1001 \\
S & 188 & L & 822 \\
S & 193 & I & 583 \\
S & 202 & N & 310 \\
\hline
\end{tabular}

957

958 


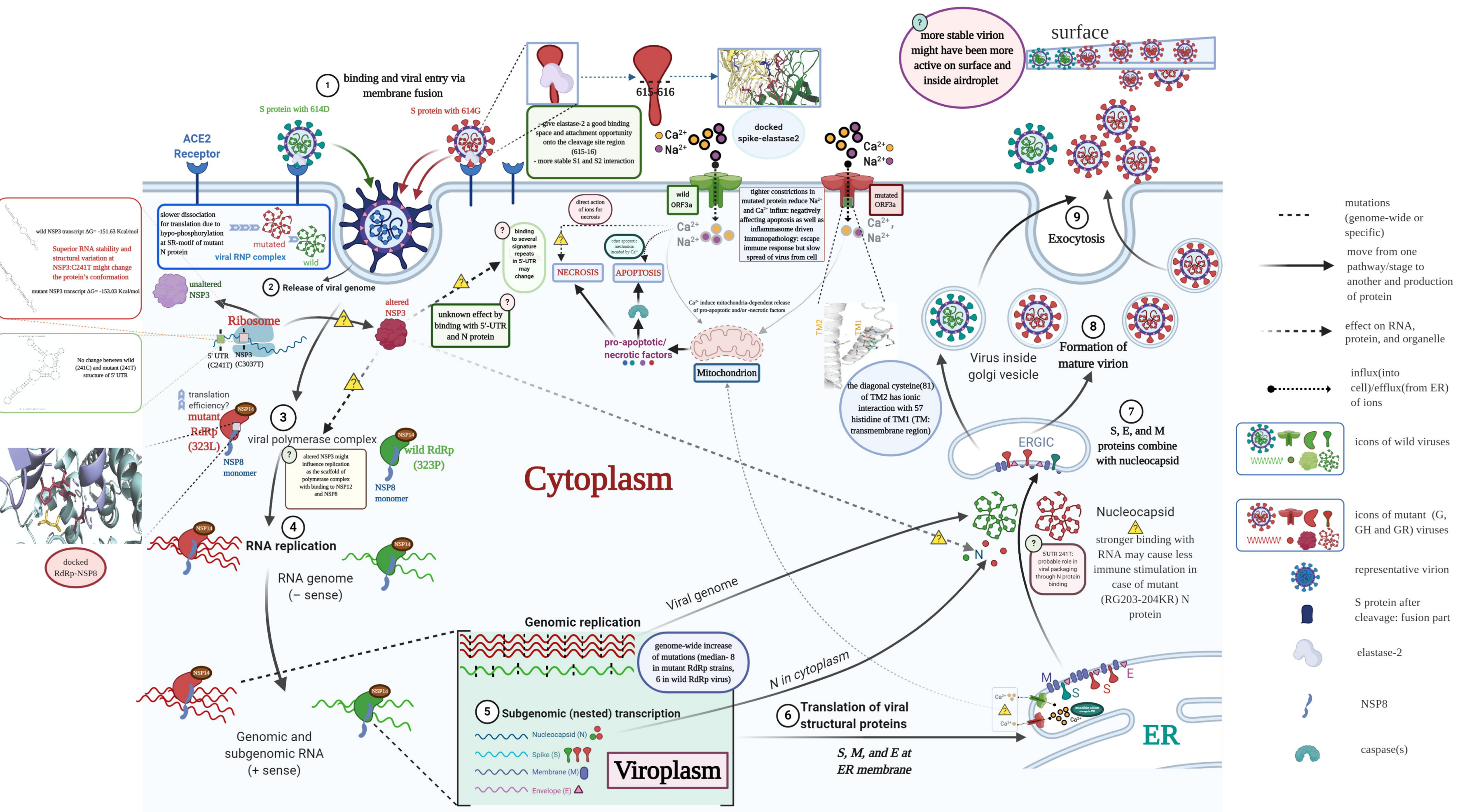




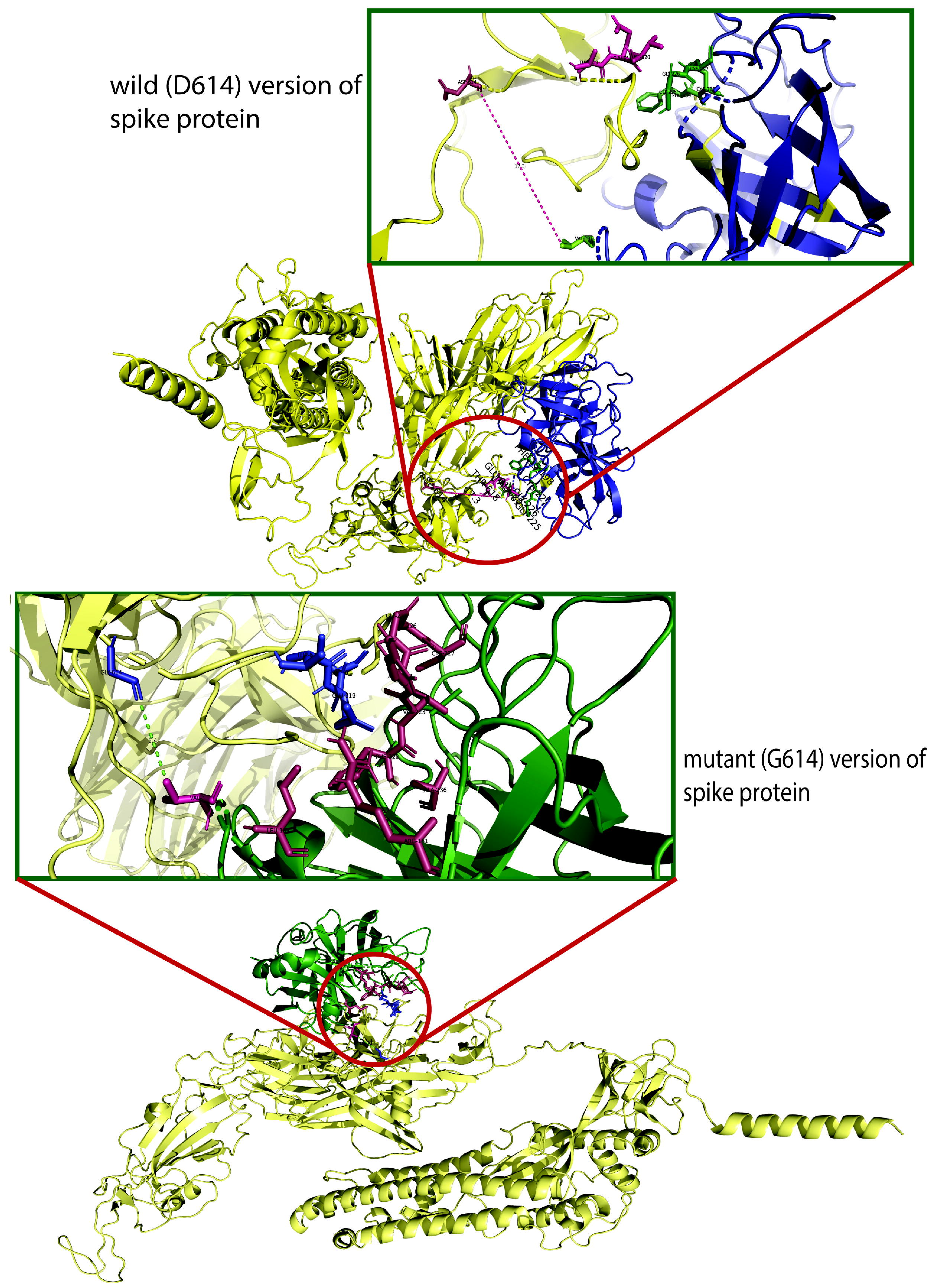




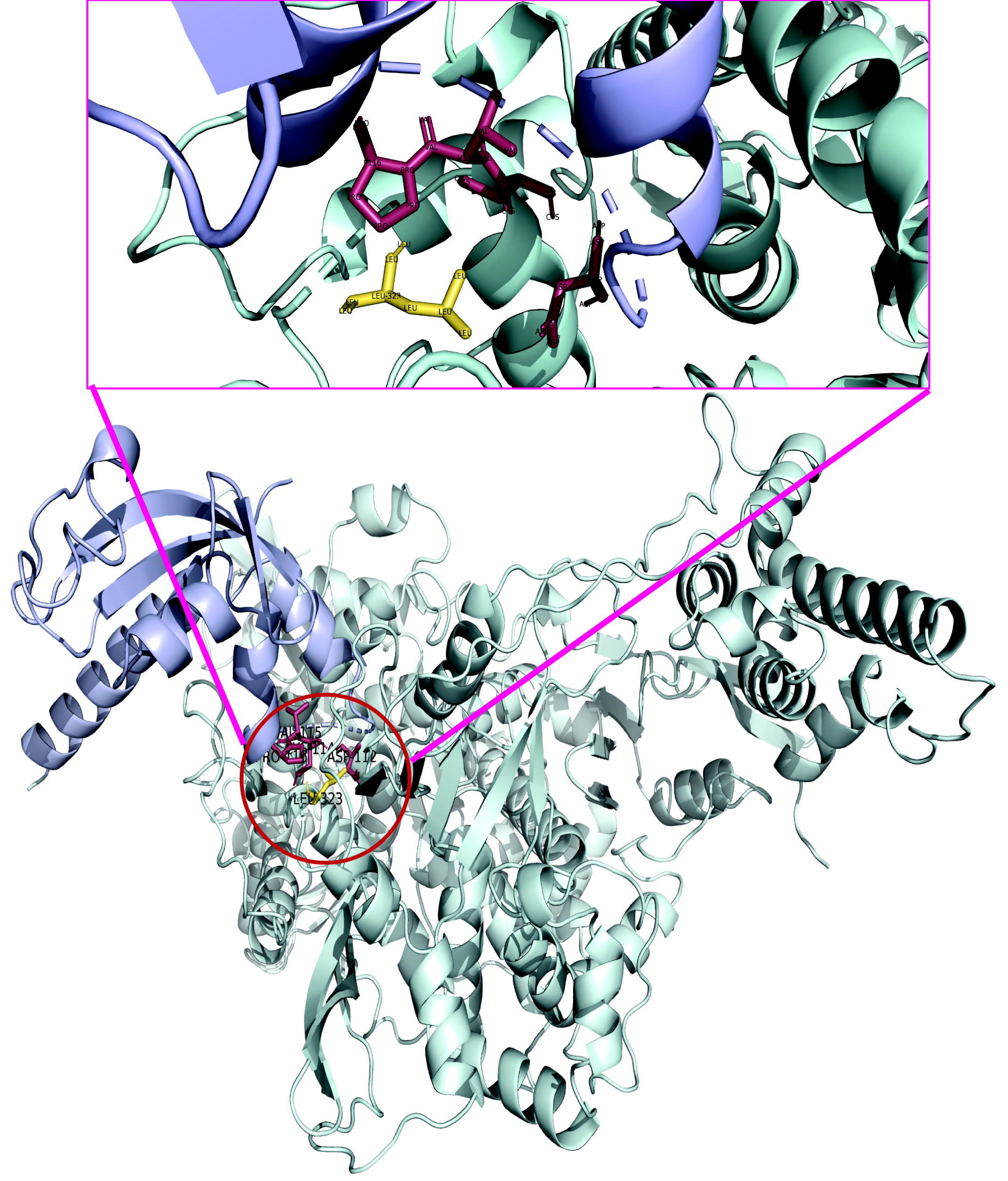





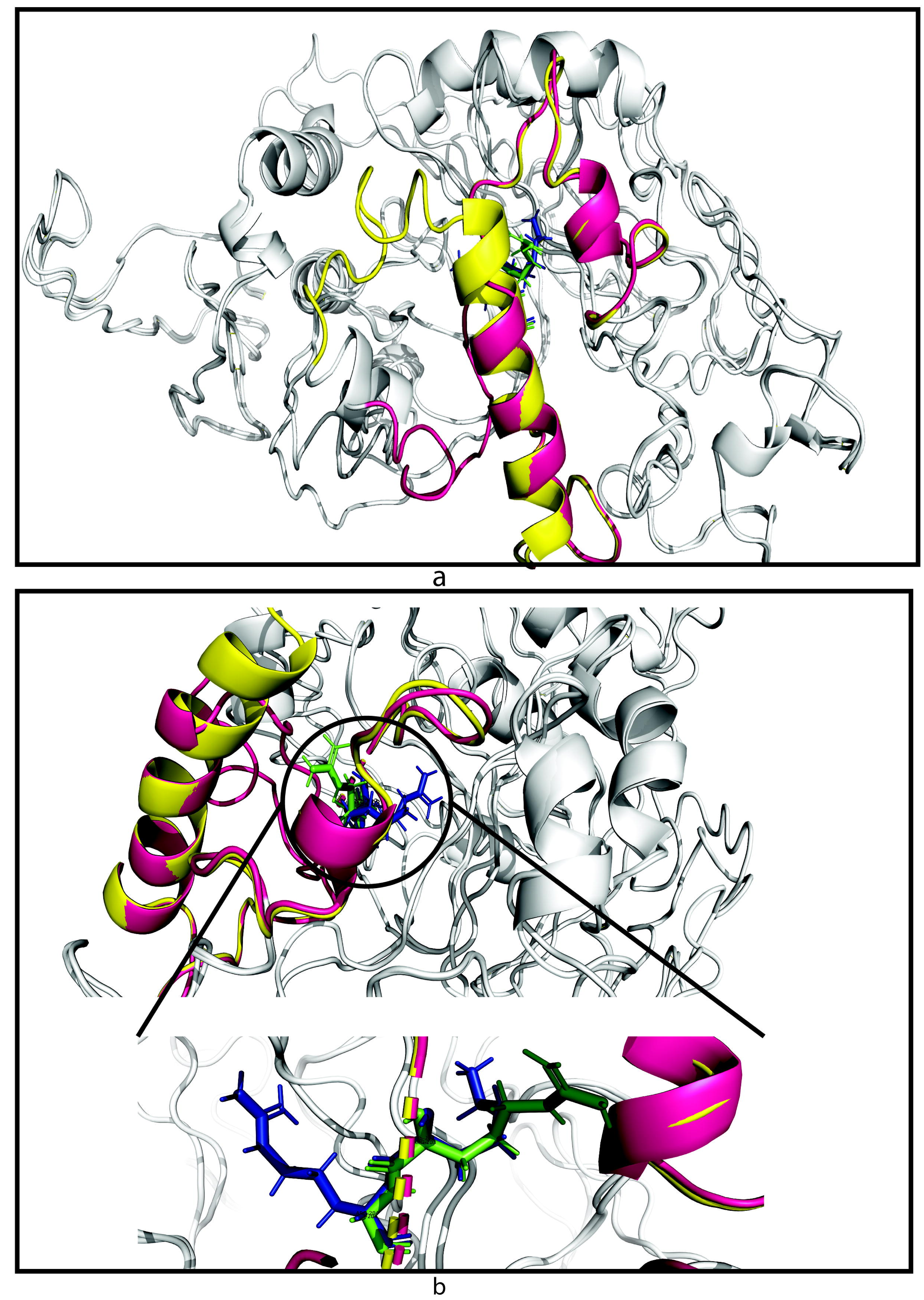